\title{
Commercial octopus species from different geographical origins: Levels of polycyclic aromatic hydrocarbons and potential health risks for consumers
}

\author{
Marta Oliveira $^{\mathrm{a}}$, Filipa Gomes ${ }^{\mathrm{a}}$, Álvaro Torrinha ${ }^{\mathrm{b}}$, Maria João Ramalhosa ${ }^{\mathrm{a}}$, \\ Cristina Delerue-Matos ${ }^{\mathrm{a}}$, Simone Morais ${ }^{\mathrm{a}, *}$ \\ ${ }^{a}$ REQUIMTE-LAQV, Instituto Superior de Engenharia, Instituto Politécnico do Porto, Rua Dr. António Bernardino de Almeida 431, 4249-015, Porto, Portugal \\ ${ }^{\mathrm{b}}$ REQUIMTE-LAQV, Laboratório de Química Aplicada, Faculdade de Farmácia, Universidade do Porto, Rua de Jorge Viterbo Ferreira, 228, 4050-313, Porto, Portugal
}

\author{
Keywords: \\ Polycyclic aromatic hydrocarbons \\ Octopus \\ Biometric characterization \\ Inter- and intra-species comparison \\ Daily intake \\ Risks \\ A B S T R A C T
}

Polycyclic aromatic hydrocarbons (PAHs) are persistent pollutants that have been raising global concern due to their carcinogenic and mutagenic properties. A total of 18 PAHs (16 USEPA priority compounds, benzo(j) fluoranthene and dibenzo(a,l)pyrene) were assessed in the edible tissues of raw octopus (Octopus vulgaris, Octopus maya, and Eledone cirrhosa) from six geographical origins available to Portuguese consumers. Inter- and intra-species comparison was statistically performed. The concentrations of total PAHs ( $\Sigma$ PAHs) ranged between 8.59 and $12.8 \mu \mathrm{g} / \mathrm{kg}$ w.w. Octopus vulgaris caught in northwest Atlantic Ocean presented $\Sigma$ PAHs significantly higher than those captured in Pacific Ocean and Mediterranean Sea, as well as than the other characterized species from western central and northeast Atlantic Ocean. PAHs with 2-3 rings were the predominant compounds (86-92\% of $\Sigma$ PAHs) but diagnostic ratios indicated the existence of pyrogenic sources in addition to petrogenic sources. Known and possible/probable carcinogenic compounds represented 11-21\% of $\Sigma$ PAHs. World and Portuguese per capita ingestion of $\Sigma$ PAHs due to cephalopods consumption varied between 1.62$2.55 \times 10^{-4}$ and 7.09-11.2 $\times 10^{-4} \mu \mathrm{g} / \mathrm{kg}$ body weight per day, respectively. Potential risks estimated for low and high consumers according to USEPA methodology suggested that a regular consumption of raw octopus does not pose public health risks.

\section{Introduction}

Cephalopods are a large group of species that live in marine environments being octopus, squids, and cuttlefish the most characterized organisms (Vecchione, 2017). Cephalopods are present in the human diet in an extensive and diverse form, being highly appreciated by some Asian (e.g. Korea, Japan, China) and some southern European countries such as Portugal, Italy, Spain and Greece (FAO, 2018). In Portugal, cephalopods, and particularly octopuses, constitute one of the most important target species in fisheries with a high economic, social and cultural value (INE, 2018). Cephalopods are usually consumed as fresh, eaten raw (e.g. sashimi) or as fresh-cooked, and in several types of processed food (e.g. dried, canned, and frozen). Fish and cephalopods are widely consumed because of their known health benefits which are mostly attributed to low fat content and high protein levels (Ke et al., 2017; Ramalhosa et al., 2012a; Torrinha et al., 2014). Food and Agriculture Organization of the United Nations (FAO) predicted an increase of $17 \%$ in the consumption of cephalopods (1989-2030) and estimated that they will represent $4 \%$ of the total species consumed in 2030 (FAO,
2007). Cephalopods are worldwide distributed living at habitats from the coastline to the edge of the continental shelf and can be found at depths ranging from surface to over $5000 \mathrm{~m}$ (Vecchione, 2017). They are active predators that feed upon shrimps, crabs, fishes, other cephalopods and bivalve mollusks (Vecchione, 2017). Cephalopods present a very small capability of metabolization and, as a consequence, they are very sensitive to the variability of their aquatic environment, reason why Semedo et al. (2012) proposed Octopus vulgaris as marine sentinel species. Thus, the presence of aquatic pollutants such as heavy metals, polycyclic aromatic hydrocarbons (PAHs), polychlorinated biphenyls among others, raises major health concern due to the potential health risks associated with a regular consumption of seafood including cephalopods, principally for the populations that appreciated them the most (Domingo et al., 2007; Gomes et al., 2013; Gu et al., 2017, 2018b; Hwang et al., 2012; Kalogeropoulos et al., 2012; Llobet et al., 2006; Martí-Cid et al., 2007, 2008; Martorell et al., 2010; Ramalhosa et al., 2012a; Semedo et al., 2012, 2014; Storelli, 2008; Unger et al., 2008; Vieira et al., 2011).

PAHs are ubiquitous persistent organic pollutants (UNECE, 1998) 
and due to their cytotoxic, mutagenic, and potential carcinogenic properties, the American Environmental Protection Agency (USEPA) listed 16 priority compounds (USEPA, 2005) while the European Commission listed 15 PAHs to be monitored in foodstuffs (European Commission, 2006, 2011). Among the priority compounds is benzo(a) pyrene (B(a)P, which is classified as carcinogenic to humans by the International Agency for Research on Cancer (IARC, group 1; IARC, 2010), and naphthalene (Naph), benz(a)anthracene (B(a)A), benzo(b) fluoranthene $(B(b) F)$, benzo(j)fluoranthene $(B(j) F)$, benzo(k)fluoranthene $(\mathrm{B}(\mathrm{k}) \mathrm{F})$, chrysene (Chry), and indeno(1,2,3-cd)pyrene (Ind) that are considered as possible carcinogenic to humans (group 2B; IARC, 2002, 2010). Dibenzo(a,l)pyrene (DB(a,l)P) and dibenz(a,h)anthracene $(\mathrm{DB}(\mathrm{a}, \mathrm{h}) \mathrm{A})$ have been also under scrutiny because they are regarded as probable carcinogens to humans (group 2A; IARC, 2010) due to their higher carcinogenic potency than B(a)P (5 and 100 for DB (a,h)A and DB(a,l)P, respectively; Boström et al., 2002; Okona-Mensah et al., 2005). PAHs are also known as endocrine disrupting chemicals (Annamalai and Namasivayam, 2015; WHO, 2013). Dietary intake has been reported as the most important route for human exposure to PAHs, except for smokers and/or occupationally exposed populations (Domingo and Nadal, 2015; Martí-Cid et al., 2008; Martorell et al., 2010; Rengarajan et al., 2015). The concentration of PAHs in foodstuffs depends on the physiological and ecological characteristics of the species, the environmental levels, and on the different ways of cooking, manufacturing and packaging the food (Domingo and Nadal, 2015; Singh et al., 2016). Raw foods reflect the background contamination (Abdel-Shafy and Mansour, 2016).

The contents of PAHs in the edible tissues of cephalopods have been evaluated by several authors, being squids and cuttlefish the most well characterized species (Bordajandi et al., 2004; Domingo et al., 2007; Fontcuberta et al., 2006; Gomes et al., 2013; Hwang et al., 2012; Ke et al., 2017; Martí-Cid et al., 2007, 2008; Martorell et al., 2010; Moon et al., 2010; Perugini et al., 2007a, 2007b; Rodríguez-Hernández et al., 2016; Semedo et al., 2014; Unger et al., 2008). To the best of our knowledge, limited information exists concerning the assessment of PAHs in the edible tissues of octopus; only common octopus (Octopus vulgaris) from northeast Atlantic Ocean (Semedo et al., 2014), argonauta argo from South China Sea (Ke et al., 2017), and seven-arm (Haliphron atlanticus) octopus from western Atlantic Ocean (Unger et al., 2008) were characterized. Other authors also assessed the levels of PAHs in common (Octopus vulgaris), giant Pacific (Octopus dofleini), and whiparm (Octopus variabilis) octopuses that were acquired from local fish markets and retailers not specifying the origin of species (Hwang et al., 2012; Moon et al., 2010; Rodríguez-Hernández et al., 2016). So far, no information exists related with the PAH levels, PAH intake and potential health risks due to the consumption of the other commercially available octopus species.

Thus, the present study aimed to characterize the PAH levels in muscle tissues of three valuable species of octopus, namely common (Octopus vulgaris), mexican four-eyed (Octopus maya), and curled (Eledone cirrhosa) octopuses captured in different geographical regions [northeast (NEA) and northwest (NWA) Atlantic Ocean; eastern (ECA) and western (WCA) Central Atlantic Ocean; Pacific Ocean (PO), and Mediterranean Sea (MS); Fig. 1]. Intra and inter-specific PAHs composition variability and the daily intake promoted by the world and Portuguese annual ingestion rates were evaluated. The potential health risks due to a regular consumption of octopus were assessed by the determination of total toxic benzo(a)pyrene equivalent and through non-carcinogenic and carcinogenic risks (USEPA, 2017).

\section{Materials and methods}

\subsection{Sample collection and characterization}

Octopus samples $(n=216)$ originated from different geographical origins were randomly purchased from different local markets in Porto region (Northwest Portugal) (Fig. 1). The collected raw species were Octopus vulgaris (common octopus; $\mathrm{n}=144$ ) from northeast (NEA) and northwest (NWA) Atlantic Ocean, eastern (ECA) and western (WCA) Central Atlantic Ocean, Pacific Ocean (PO), and Mediterranean Sea (MS); Octopus maya (mexican four-eyed octopus; $\mathrm{n}=48$ ) from western Central Atlantic Ocean (WCA); and Eledone cirrhosa (curled octopus;

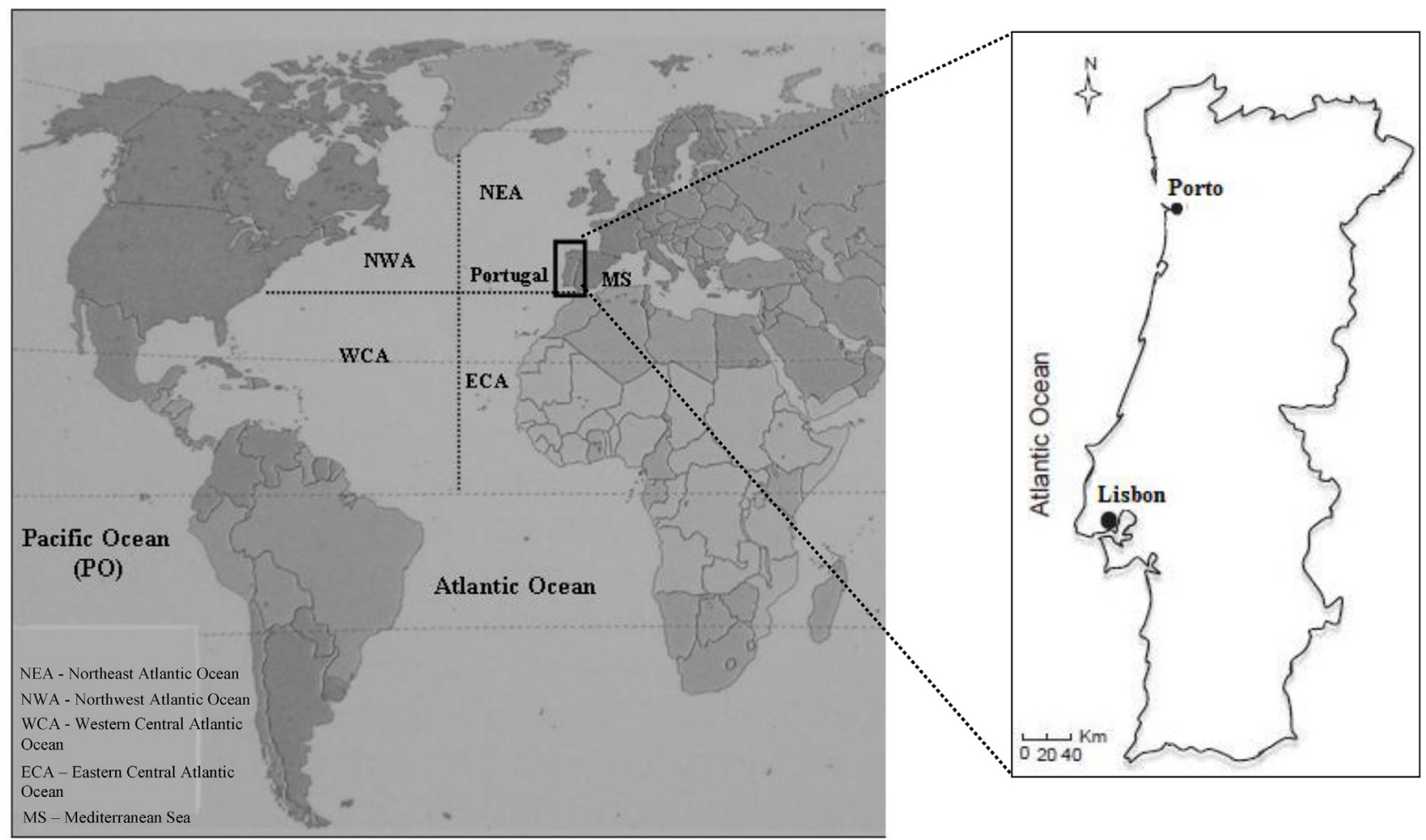

Fig. 1. Identification of the different geographical origins available in the local markets of Porto (NW Portugal). 
$n=24$ ) from NEA. The origin of each octopus sample was established according to the label information. Samples were transported to the laboratory in clean polyethylene bags and processed immediately after collection. Sample collection, biometric characterization and preparation were performed according to the EPA Guide No. 823-B-00-07 and EC Regulation No. 333/2007. Each sample was weighed, its mantle, arms and total lengths were measured and, then, each octopus was manually eviscerated. Only the edible tissues (mantle and arms) were preserved and grinded (Moulinex $700 \mathrm{~W}$, A320R1, Indonesia). Moisture content was determined according to the national (Portuguese Standard NP 2282-1991) and international (official AOAC method; AOAC, 2007) recommendations. Total fat content was extracted with $30.0 \mathrm{~mL}$ of acetone:ether petroleum (1:2) by microwave-assisted extraction accordingly with Ramalhosa et al. (2012a). Samples were frozen in polycarbonate containers at $-20^{\circ} \mathrm{C}$ until analysis.

\subsection{Extraction and chromatographic analysis of PAHs}

A total of 18 PAHs (16 USEPA priority compounds, B(j)F and DB(a,l) P) were microwave-assisted extracted with a MARS-X $1500 \mathrm{~W}$ (Microwave Accelerated Reaction System for Extraction and Digestion, CEM, Mathews, NC, USA) and quantified by liquid chromatography with fluorescence and photodiode array detection as previously described by Ramalhosa et al. (2009, 2012b). A more detailed description of the analytical procedure is given in Section $1 \mathrm{~S}$ of the Supplementary Material, including the chromatographic characteristics (Table 1S) and quality control of the methodology used for the extraction and quantification of PAHs in the edible tissues of octopus samples. Chromatographic analyses were conducted in triplicate. $\mathrm{PAH}$ levels were determined on wet and dry weight basis, however, in order to simplify the discussion, results are only presented on wet weight (w.w.) basis.

\subsection{Risk assessment}

To estimate the potential public health risks associated with the intake of PAHs, the average per capita of the world ( $0.51 \mathrm{~kg}$ per capita per year) and Portuguese consumption (2.23 kg per capita per year) for the year of 2013 (FAO, 2018) was used for adults ( $\geq 21$ years) with a mean weight of $70 \mathrm{~kg}$ (USEPA, 2011). With this approach, it is believed that potential public health risks for low and top consumers were estimated. Risks were evaluated through the determination of total toxic benzo(a)pyrene equivalent $\left(\mathrm{TEQ}_{\mathrm{B}(\mathrm{a}) \mathrm{P}}\right)$ by considering the toxicity equivalency factors (TEF) reported by Muller et al. (1997), Nisbet and
LaGoy (1992) and Okona-Mensah et al. (2005) (Table 2S). This evaluation is based on the relative potency of each PAH toxicity compared with the only known human carcinogen, B(a)P (IARC, 2010). Noncarcinogenic risks assessed by the target hazard quotient (THQ) and carcinogenic risks (TR) were also determined according to the methodology provided by USEPA Region III Risk-based Concentration Table (USEPA, 2017). THQ were only determined for Naph, acenaphthene (Ace), fluorene (Flu), anthracene (Ant), fluoranthene (Fln) and pyrene (Py), since for these PAHs an oral reference dose was established (USEPA, 2017). TR were calculated for B(a)A, Chry, B(b+j)F, B(k)F, B (a)P, and DB(a,h)A once the oral carcinogenic slope factor is already defined for these compounds. An example of the determination of THQ and TR for the consumption of octopus edible tissues is presented in Tables $3 S$ and $4 S$, respectively.

\subsection{Statistical analysis}

Statistical analyses were performed using the SPSS (IBM SPSS Statistics 20), Statistica (v. 7, StatSoft Inc., USA), and Excel (v. 16.0, Microsoft Corporation, USA) programmes. PAH concentrations were compared through the nonparametric Mann-Whitney $U$ test, since normal distribution was not observed by Shapiro-Wilk's test. Spearman correlation coefficients were determined to estimate the dependence of biometric parameters (weight, lengths, moisture and fat contents) on the levels of PAHs found in the edible tissues of the octopus species. Statistical significance was defined as $p \leq 0.05$.

\section{Results and discussion}

\subsection{Biometric characterization of the octopus species}

The biometric data (mantle, arms, and total lengths), weight, moisture, and fat contents of the collected octopus species from different geographical origins are exhibited in Table 1. Generally, Octopus vulgaris presented the highest median mantle length $(\mathrm{MS}>\mathrm{PO}>$ NWA > NEA > WCA > ECA), followed by Octopus maya from WCA and Eledone cirrhosa from ECA. The mantle length of Octopus vulgaris caught in NWA, WCA, and MS were significantly different $(p=0.013)$ from all the other origins for the same species (except for those originated from NEA), but also from Octopus maya and Eledone cirrhosa. This species captured in NEA were significantly smaller than all the other octopus samples $(p<0.001$ for arms length; $p=0.013$ for mantle length). These findings are in line with the median weight observed for

Table 1

Zone of capture ${ }^{\mathrm{a}}$, biometric data, moisture and fat contents (mean, median, and range) of the characterized octopus species.

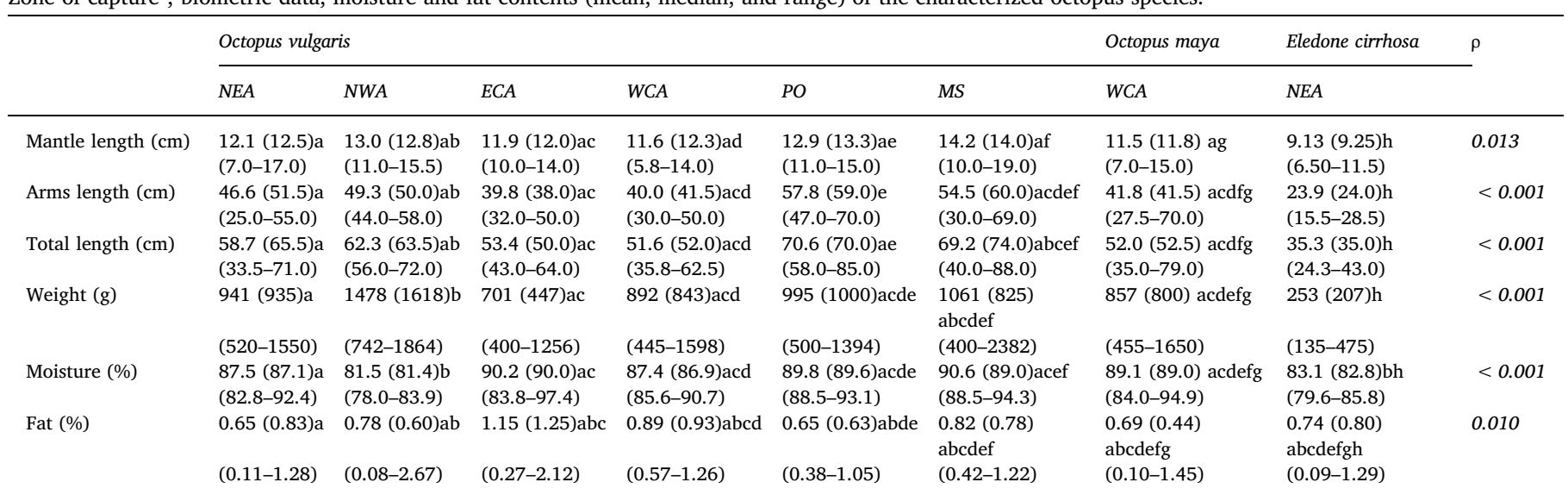

${ }^{a}$ The same letter in a row indicates that the given median are not statistically different $(\mathrm{p}>0.05)$. Each letter $(\mathrm{a}-\mathrm{h})$ corresponds to a species and inherent origin (a, O. vulgaris from Northeast Atlantic Ocean (NEA); b, O. vulgaris from Northwest Atlantic Ocean (NWA); c, O. vulgaris from Eastern Central Atlantic Ocean (ECA); d, $O$. vulgaris from Western Central Atlantic Ocean (WCA); e, O. vulgaris from Pacific Ocean (PO); f, O. vulgaris from Mediterranean Sea (MS); g, O. maya from WCA; h, E. cirrhosa from NEA). 
each specie: 447 (ECA) to $1618 \mathrm{~g}$ (NWA) for Octopus vulgaris, $800 \mathrm{~g}$ for Octopus maya and $207 \mathrm{~g}$ for Eledone cirrhosa ( $p<0.001$; Table 1).

Cephalopods are known for their high moisture and low fat contents (Ozogul et al., 2008; Torrinha et al., 2014). Overall, moisture median content was $89.0 \%$ for Octopus maya, $82.8 \%$ for Eledone cirrhosa and ranged between 81.4 (NWA) to $90.0 \%$ (ECA) for Octopus vulgaris, (Table 1). Once again, Eledone cirrhosa octopuses presented one of the lowest contents being the range of moistures significantly different $(p<0.001)$ from all the other samples, except from Octopus vulgaris captured in NWA. Regarding fat levels, medians ranged from 0.44 (Octopus maya, WCA) to $1.25 \%$ (Octopus vulgaris, ECA) (Table 1); statistical differences $(p=0.010)$ were only detected between ECA and PO for Octopus vulgaris.

\section{2. $P A H$ concentrations}

\subsubsection{Inter- and intra-species comparison}

PAHs are bioavailable to marine organisms through the food chain, as waterborne compounds, and from contaminated sediments (Gu et al., 2018a; Olenycz et al., 2015; Ramalhosa et al., 2012a; Robinson et al., 2017; Tongo et al., 2017; Wolska et al., 2012). PAHs accumulation in seafood depends on the species metabolic capacity (fish > crustaceans $>$ molluscs that include cephalopods), season, and the levels of pollutants in the aquatic environment (Bansal and Kim, 2015). The mean and median concentrations of individual and total PAHs ( $\mathrm{PAHs}$ ) in the edible tissues of octopus samples are presented in Table 2. Among the 18 PAHs considered, phenanthrene (Phe) was detected in more than $88 \%$ of the samples; Naph, Flu, and Ace in $13-88 \%$ of the octopus; and the other 14 compounds reached $50 \%$ of detection rate. Ind was never detected, thus it was excluded from further analysis.

The order describing the inter- and intra-species comparison of $\Sigma$ PAHs medians was: Octopus vulgaris NWA $>$ ECA $>$ WCA $>$ NEA $>$ Eledone cirrhosa NEA $>$ Octopus vulgaris $\mathrm{MS}>\mathrm{PO}>$ Octopus maya WCA (Table 2). Thus, in general, Octopus vulgaris exhibited the highest concentrations of $\Sigma$ PAHs (8.59-12.8 $\mu \mathrm{g} / \mathrm{kg}$ w.w.) and Octopus maya the lowest. Octopus vulgaris caught in NWA waters presented $\Sigma$ PAH median concentrations significantly higher $(p \leq 0.050)$ than those captured in PO and MS, as well as the other characterized species (Octopus maya and Eledone cirrhosa). Octopus maya displayed significantly lower levels than Eledone cirrhosa and Octopus vulgaris from NWA, ECA and WCA. The median concentrations of $\Sigma$ PAHs determined in the edible tissues of octopuses available for Portuguese consumers $(8.12-12.8 \mu \mathrm{g} / \mathrm{kg}$ w.w.) were in the same range of those reported by Semedo et al. (2014) in the arms of Octopus vulgaris $(0.25-13.6 \mu \mathrm{g} / \mathrm{kg}$

Table 2

PAH contents ${ }^{\mathrm{a}, \mathrm{b}}$ (mean, median, range and total ( $\left.\Sigma \mathrm{PAHs}\right) ; \mu \mathrm{g} / \mathrm{kg}$ wet weight) in edible tissues of the characterized octopus species.

\begin{tabular}{|c|c|c|c|c|c|c|c|c|c|}
\hline \multirow[t]{2}{*}{ PAHs } & \multicolumn{6}{|l|}{ Octopus vulgaris } & \multirow{2}{*}{$\begin{array}{l}\text { Octopus maya } \\
W C A\end{array}$} & \multirow{2}{*}{$\begin{array}{l}\text { Eledone cirrhosa } \\
\text { NEA }\end{array}$} & \multirow[t]{2}{*}{$\rho$} \\
\hline & $N E A$ & $N W A$ & $E C A$ & WCA & $P O$ & MS & & & \\
\hline Naph & $\begin{array}{l}1.14(0.50) \mathrm{ac} \\
(0.50-2.52)\end{array}$ & $\begin{array}{l}0.88(0.50) \mathrm{ac} \\
(0.50-1.76)\end{array}$ & $\begin{array}{l}0.86(0.89) a \\
(0.50-1.73)\end{array}$ & $\begin{array}{l}1.18(0.50) a c \\
(0.50-3.22)\end{array}$ & $\begin{array}{l}0.71(0.62) \mathrm{a} \\
(0.50-1.07)\end{array}$ & $\begin{array}{l}0.81(0.50) \mathrm{a} \\
(0.50-1.51)\end{array}$ & $\begin{array}{l}0.62(0.50) \mathrm{b} \\
(0.50-1.63)\end{array}$ & $\begin{array}{l}1.09(1.24) c \\
(0.50-1.39)\end{array}$ & $\leq 0.034$ \\
\hline Acen & $\begin{array}{l}8.09(5.76) \mathrm{a} \\
(5.76-27.3)\end{array}$ & $\begin{array}{l}7.50(5.76) \mathrm{ab} \\
(5.76-15.4)\end{array}$ & $\begin{array}{l}21.5(8.35) c \\
(5.76-63.8)\end{array}$ & $\begin{array}{l}16.1(5.76) \text { abcd } \\
(5.76-54.4)\end{array}$ & $\begin{array}{l}10.1(5.76) \text { abde } \\
(5.76-34.4)\end{array}$ & 5.76abef & $\begin{array}{l}10.6 \text { (5.76)aefg } \\
(5.76-84.0)\end{array}$ & 5.76afgh & $\leq 0.043$ \\
\hline Ace & $\begin{array}{l}1.52(1.42) \mathrm{a} \\
(0.39-3.90)\end{array}$ & $\begin{array}{l}2.72(1.57) \mathrm{ab} \\
(0.39-10.3)\end{array}$ & $\begin{array}{l}0.46(0.39) c \\
(0.39-0.98)\end{array}$ & $\begin{array}{l}1.52(0.76) \mathrm{abd} \\
(0.39-4.89)\end{array}$ & $\begin{array}{l}0.48(0.39) c e \\
(0.39-1.02)\end{array}$ & $\begin{array}{l}0.77(0.39) \text { cef } \\
(0.39-2.05)\end{array}$ & $\begin{array}{l}0.88(0.39) \mathrm{dfg} \\
(0.39-2.89)\end{array}$ & $\begin{array}{l}0.55(0.56) b f g \\
(0.39-0.79)\end{array}$ & $\leq 0.050$ \\
\hline Flu & $\begin{array}{l}0.14(0.06) \mathrm{a} \\
(0.06-0.48)\end{array}$ & $\begin{array}{l}0.28(0.26) \mathrm{b} \\
(0.06-0.52)\end{array}$ & $\begin{array}{l}0.22(0.25) c \\
(0.06-0.45)\end{array}$ & $\begin{array}{l}0.11(0.06) \mathrm{ad} \\
(0.06-0.23)\end{array}$ & $\begin{array}{l}0.13(0.10) \text { acde } \\
(0.06-0.28)\end{array}$ & $\begin{array}{l}0.08(0.06) \mathrm{adf} \\
(0.06-0.15)\end{array}$ & $\begin{array}{l}0.10(0.10) \text { adeg } \\
(0.06-0.18)\end{array}$ & $\begin{array}{l}0.22(0.13) \text { bceh } \\
(0.06-0.55)\end{array}$ & $\leq 0.050$ \\
\hline Phe & $\begin{array}{l}0.38(0.39) a \\
(0.21-0.66)\end{array}$ & $\begin{array}{l}0.63(0.64) \mathrm{b} \\
(0.04-1.09)\end{array}$ & $\begin{array}{l}0.53(0.41) a c \\
(0.24-1.48)\end{array}$ & $\begin{array}{l}0.35(0.29) \mathrm{ad} \\
(0.18-0.79)\end{array}$ & $\begin{array}{l}0.53(0.50) \mathrm{e} \\
(0.36-0.75)\end{array}$ & $\begin{array}{l}0.45(0.42) \mathrm{acf} \\
(0.27-0.80)\end{array}$ & $\begin{array}{l}0.33(0.30) \mathrm{dg} \\
(0.18-0.62)\end{array}$ & $\begin{array}{l}0.46(0.46) \mathrm{cfh} \\
(0.30-0.63)\end{array}$ & $\leq 0.048$ \\
\hline Ant & $0.06 \mathrm{a}$ & $\begin{array}{l}0.15(0.06) \mathrm{b} \\
(0.06-0.42)\end{array}$ & $0.06 \mathrm{a}$ & $0.06 \mathrm{a}$ & $0.06 \mathrm{a}$ & $0.06 \mathrm{a}$ & $0.06 \mathrm{a}$ & $\begin{array}{l}0.14(0.06) b c \\
(0.06-0.46)\end{array}$ & $\leq 0.006$ \\
\hline Fln & $\begin{array}{l}0.17(0.08) a \\
(0.08-0.81)\end{array}$ & $\begin{array}{l}0.30(0.08) a b \\
(0.08-1.13)\end{array}$ & $\begin{array}{l}0.83(0.92) c \\
(0.08-2.25)\end{array}$ & $0.08 \mathrm{ad}$ & $\begin{array}{l}0.38(0.08) \text { bce } \\
(0.08-1.42)\end{array}$ & $\begin{array}{l}0.20(0.08) \text { abdef } \\
(0.08-0.65)\end{array}$ & $0.08 \mathrm{dg}$ & 0.08adfgh & $\leq 0.03$ \\
\hline Py & $\begin{array}{l}0.09(0.07) \mathrm{a} \\
(0.07-0.27)\end{array}$ & $\begin{array}{l}0.08(0.07) \mathrm{ab} \\
(0.07-0.17)\end{array}$ & $\begin{array}{l}0.13(0.07) \mathrm{ac} \\
(0.07-0.27)\end{array}$ & 0.07abd & $\begin{array}{l}0.10(0.07) \text { ace } \\
(0.07-0.24)\end{array}$ & $\begin{array}{l}0.31(0.07) \text { abcdef } \\
(0.07-1.07)\end{array}$ & $\begin{array}{l}0.08(0.07) \text { abdfg } \\
(0.07-0.16)\end{array}$ & $\begin{array}{l}0.15(0.07) \text { cefh } \\
(0.07-0.34)\end{array}$ & $\leq 0.028$ \\
\hline $\mathrm{B}(\mathrm{a}) \mathrm{A}$ & $0.05 a$ & $\begin{array}{l}0.14(0.05) \mathrm{ab} \\
(0.05-1.18)\end{array}$ & $0.05 a b$ & $0.05 a b c$ & $0.05 \mathrm{abcd}$ & 0.05abcde & 0.05 acdef & $\begin{array}{l}0.12(0.05) \mathrm{bg} \\
(0.05-0.50)\end{array}$ & $\leq 0.040$ \\
\hline Chry & 0.04 & 0.04 & 0.04 & 0.04 & 0.04 & 0.04 & 0.04 & $\begin{array}{l}0.20(0.04) \\
(0.04-0.70)\end{array}$ & c \\
\hline$B(b+j) F$ & $0.21 \mathrm{a}$ & $0.21 \mathrm{a}$ & $0.21 \mathrm{a}$ & $0.21 \mathrm{a}$ & $0.21 \mathrm{a}$ & $\begin{array}{l}0.25(0.21) a b \\
(0.21-0.52)\end{array}$ & $\begin{array}{l}0.22(0.21) \mathrm{b} \\
(0.21-0.41)\end{array}$ & $0.21 \mathrm{ab}$ & $\leq 0.05$ \\
\hline $\mathrm{B}(\mathrm{k}) \mathrm{F}$ & $\begin{array}{l}0.03(0.03) \mathrm{a} \\
(0.03-0.08)\end{array}$ & $0.03 \mathrm{ab}$ & $0.03 \mathrm{abc}$ & 0.03abcd & 0.03abcde & 0.03abcde & 0.03 bcdef & $\begin{array}{l}0.04(0.03) \mathrm{ag} \\
(0.03-0.10)\end{array}$ & $\leq 0.013$ \\
\hline $\mathrm{B}(\mathrm{a}) \mathrm{P}$ & $\begin{array}{l}0.07(0.06) \mathrm{a} \\
(0.05-0.12)\end{array}$ & $0.06 \mathrm{a}$ & $0.06 a$ & $0.06 a$ & $0.06 a$ & $0.06 a$ & $0.06 a$ & $\begin{array}{l}0.07(0.06) \mathrm{a} \\
(0.06-0.13)\end{array}$ & $\geq 0.05$ \\
\hline $\mathrm{DB}(\mathrm{a}, \mathrm{h}) \mathrm{A}$ & 0.12 & 0.12 & 0.12 & 0.12 & $\begin{array}{l}0.47(0.12) \\
(0.12-2.58)\end{array}$ & 0.12 & 0.12 & 0.12 & c \\
\hline $\mathrm{B}(\mathrm{g}, \mathrm{h}, \mathrm{i}) \mathrm{P}$ & 0.08 & 0.08 & 0.08 & 0.08 & 0.08 & 0.08 & 0.08 & $\begin{array}{l}0.11(0.08) \\
(0.08-0.23)\end{array}$ & c \\
\hline $\mathrm{DB}(\mathrm{a}, \mathrm{l}) \mathrm{P}$ & 0.16 & $\begin{array}{l}0.18(0.16) \\
(0.16-0.27)\end{array}$ & 0.16 & 0.16 & 0.16 & 0.16 & 0.16 & 0.16 & $\mathrm{c}$ \\
\hline$\Sigma$ PAHs & $\begin{array}{l}12.2(9.7) \mathrm{a} \\
(7.98-31.8)\end{array}$ & 13.4 (12.8)ab (9.69-18.9) & $\begin{array}{l}23.4(11.7) \mathrm{abc} \\
(8.32-67.4)\end{array}$ & $\begin{array}{l}18.1 \text { (11.0)abcd } \\
(8.03-59.5)\end{array}$ & $\begin{array}{l}12.5 \text { (8.59)acde } \\
(8.10-37.0)\end{array}$ & $\begin{array}{l}9.1 \text { (8.65)acdef } \\
(8.52-10.6)\end{array}$ & $\begin{array}{l}13.5 \text { (8.12)aefg } \\
(7.92-86.3)\end{array}$ & $\begin{array}{l}9.36(9.23) \text { acdefh } \\
(8.99-10.3)\end{array}$ & $\leq 0.050$ \\
\hline
\end{tabular}

Naph - naphthalene, Acen - acenaphthylene, Ace - acenaphthene, Flu - fluorene, Phe - phenanthrene, Ant - anthracene, Fln - fluoranthene, $P y$ - pyrene, $B(a) A$ - benz (a)anthracene, Chry - chrysene, $B(b+j) F$ - benzo(b $+\mathrm{j})$ fluoranthene, $B(k) F$ - benzo(k)fuoranthene, $B(a) P$ - benzo(a)pyrene, $D B(a, h) A-\operatorname{dibenz}(\mathrm{a}, \mathrm{h})$ anthracene, $B$ $(g, h, i) P$ - benzo(g,h,i)perylene, DB(a,l)P - dibenzo(a,l)pyrene.

${ }^{a}$ When the concentration of a compound was below the detection limit (LOD), the value of the respective LOD/V2 was used (Hornung and Reed, 1990).

b The same letter in a row indicate that the given median are not statistically different $(\mathrm{p}>0.05)$. Each letter $(\mathrm{a}-\mathrm{h})$ corresponds to a species and inherent origin (a, O. vulgaris from Northeast Atlantic Ocean (NEA); b, O. vulgaris from Northwest Atlantic Ocean (NWA); c, O. vulgaris from Eastern Central Atlantic Ocean (ECA); d, O. vulgaris from Western Central Atlantic Ocean (WCA); e, O. vulgaris from Pacific Ocean (PO); f, O. vulgaris from Mediterranean Sea (MS); g, O. maya from WCA; h, E. cirrhosa from NEA).

c Number of values higher than the limit of detection was insufficient for statistical analysis. 


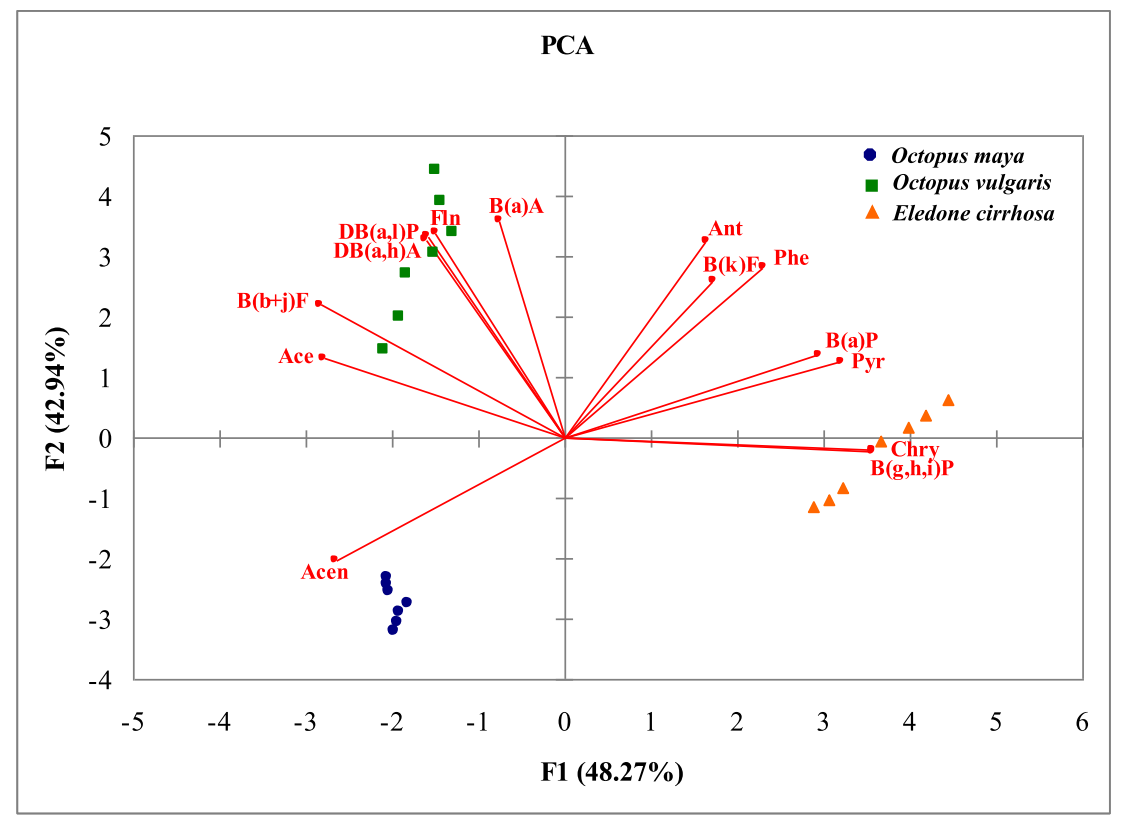

Fig. 2. Principal components analysis (PCA) of the studied species (Octopus maya, Eledone cirrhosa, and Octopus vulgaris) based on the detected PAH concentrations. Only samples that had levels of all selected PAHs higher than the limit of detection were used.

w.w.) caught by local fishermen along the northwest coast of Portugal, but lower than the levels determined in cuttlefish (Sepia esculenta: $21.8 \mu \mathrm{g} / \mathrm{kg}$ w.w.) and squid (Todarodes sagittatus: $14.74-71.23 \mu \mathrm{g} / \mathrm{kg}$ w.w.; Loligo duvaucelii: $9.16 \mu \mathrm{g} / \mathrm{kg}$ w.w.; Loligo vulgaris: $45.4 \mu \mathrm{g} / \mathrm{kg}$ w.w.; Loligo reynaudii: $58.6 \mu \mathrm{g} / \mathrm{kg}$ w.w.; Loligo gahi: $26.9 \mu \mathrm{g} / \mathrm{kg}$ w.w.; Loligo opalescens: $15.1 \mu \mathrm{g} / \mathrm{kg}$ w.w.) originated from Central Adriatic Sea (Perugini et al., 2007a), Gulf of Naples - Tyrrhenian Sea, Italy (Perugini et al., 2007b), Indic, Pacific and Atlantic Oceans (Gomes et al., 2013). Also, the $\Sigma$ PAHs detected in this study were predominantly higher than those found in cuttlefish (Sepia esculenta: $1.25-3.0 \mu \mathrm{g} / \mathrm{kg}$ w.w.; Todarodes pacificus: $0.9 \mu \mathrm{g} / \mathrm{kg}$ w.w.), squid (Loligo vulgaris: $1.2-3.0 \mu \mathrm{g} / \mathrm{kg}$ w.w.), and octopus (Octopus variabilis: $1.9 \mu \mathrm{g} / \mathrm{kg}$ w.w.; Octopus dofleini: $1.2 \mu \mathrm{g} / \mathrm{kg}$ w.w.) samples purchased from local fish markets, supermarkets, and grocery stores from different cities of Catalonia, Spain (Domingo et al., 2007; Llobet et al., 2006; Martí-Cid et al., 2007, 2008; Martorell et al., 2010) and Korea (Hwang et al., 2012). Still, the comparison of $\Sigma$ PAHs between studies may be done with caution since different number of PAHs (including different compounds) are frequently considered.

Fig. 2 shows the principal component analysis (PCA) for the PAHs data set organized by species, regardless of their geographical origin. Factors with eigenvalues $>1$ were extracted and Kaiser-Meyer-Olkin (KMO) measure of sampling adequacy $>0.5$ was used (Naph and Flu were excluded; KMO $<0.5$ ). The PCA model resulted in two significant factors (F1 and F2) that represented $91.21 \%$ of the total variability (Table 5S). F1 contributed with $48.27 \%$ of the original data with high loadings $(0.552 \leq$ square cosines values $\leq 0.993)$ for acenaphthylene (Acen), Ace, Py, Chry, B(b+j)F, B(a)P, and benzo(g,h,i)perylene (B $(\mathrm{g}, \mathrm{h}, \mathrm{i}) \mathrm{P})$. This factor allowed discrimination of Eledone cirrhosa samples from the other octopus species. Chry and $\mathrm{B}(\mathrm{g}, \mathrm{h}, \mathrm{i}) \mathrm{P}$ presented the highest discriminant power (square cosines values $=0.993$ ) for the differentiation of Eledone cirrhosa mostly because these two PAHs were only detected in the edible tissues of this species (Table 2). F2 represented $42.94 \%$ of the original data variance and was highly loaded by Phe, Ant, Fln, B(a)A, B(k)F, DB(a,h)A, and DB(a,l)P (square cosines $>0.473)$. This function mainly enables to differentiate mexican four-eyed samples from common octopuses (Fig. 2). Acen strongly contributed for the discrimination of Octopus maya species (square cosines values $=0.552$ ) and, despite the detection of this compound also in Octopus vulgaris from NEA, NWA, ECA, NWA, and PO, the highest range of concentrations were exhibited by Octopus maya samples (5.76-84.0 $\mu \mathrm{g} / \mathrm{kg}$ w.w; Table 2). Ace, Fln, B(a)A, B(b+j)F, DB(a,h)A, $\mathrm{DB}(\mathrm{a}, 1) \mathrm{P}$ were the compounds that contributed the most (square cosines values $>0.619$ ) to separate Octopus vulgaris samples from the other species (Fig. 2); Fln, $\mathrm{DB}(\mathrm{a}, \mathrm{h}) \mathrm{A}$, and $\mathrm{DB}(\mathrm{a}, \mathrm{l}) \mathrm{P}$ were only found in the muscle tissues of Octopus vulgaris (Table 2). Phe, Ant, Py, B(a)P, and B (k)F also presented moderate to high loadings (square cosines values $>0.473$ ), however they contributed less to differentiate the three species of octopus (Fig. 2).

Overall, compounds with two (Naph) and three (Acen, Ace, Flu, Phe, and Ant) aromatic rings were the most predominant, accounting with $86-92 \%$ of $\Sigma$ PAHs (Fig. 1S of the Supplementary Material). Acen was the most abundant PAH (56-92\% of $\Sigma$ PAHs), being followed by Ace $(2-20 \%$ of $\Sigma$ PAHs), Naph $(4-12 \%$ of $\Sigma$ PAHs), and Phe $(2-5 \%$ of $\Sigma$ PAHs). Altogether, these four compounds represented $84-90 \%$ of $\Sigma$ PAHs in the analysed edible tissues. The concentrations of Acen (5.76-63.8 $\mu \mathrm{g} / \mathrm{kg}$ w.w.) and Ace (0.39-0.98 $\mu \mathrm{g} / \mathrm{kg}$ w.w.) in ECA Octopus vulgaris were only similar with those of Octopus vulgaris from WCA $(p \leq 0.023)$ and with those caught in PO and MS $(p \leq 0.020)$, respectively (Table 2). Flu levels in Octopus vulgaris from NWA $(0.06-0.52 \mu \mathrm{g}$ / $\mathrm{kg}$ w.w.) and ECA (0.06-0.45 $\mu \mathrm{g} / \mathrm{kg}$ w.w.) were significantly different between each other $(p=0.012)$ and significantly higher than in the other octopuses, except for Octopus vulgaris caught in $\mathrm{PO}$ and Eledone cirrhosa $(p \leq 0.030)$. Regarding Phe concentrations, it was observed that Octopus vulgaris captured in NWA $(0.04-1.09 \mu \mathrm{g} / \mathrm{kg}$ w.w.) and PO $(0.36-0.75 \mu \mathrm{g} / \mathrm{kg}$ w.w.) were significantly different between each other $(p=0.048)$ and also significantly higher than in other species ( $p \leq 0.048$ ). Compounds with four (Fln, $\mathrm{Py}, \mathrm{B}(\mathrm{a}) \mathrm{A}$, and Chry), five (B(b $+\mathrm{j}) \mathrm{F}, \mathrm{B}(\mathrm{k}) \mathrm{F}, \mathrm{B}(\mathrm{a}) \mathrm{P}$, and $\mathrm{DB}(\mathrm{a}, \mathrm{h}) \mathrm{A})$, and six $(\mathrm{B}(\mathrm{g}, \mathrm{h}, \mathrm{i}) \mathrm{P}$ and $\mathrm{DB}(\mathrm{a}, \mathrm{l}) \mathrm{P})$ aromatic rings contributed with $2-8 \%, 3-7 \%$, and $2-3 \%$ of $\Sigma \mathrm{PAHs}$, respectively (Fig. 1S). These findings are in line with the distribution of PAHs described by other authors in squid and octopus samples among other marine organisms (Bordajandi et al., 2004; Gomes et al., 2013; Hwang et al., 2012; Ke et al., 2017; Moon et al., 2010; Perugini et al., 2007a; Ramalhosa et al., 2012a; Semedo et al., 2014; Tongo et al., 2017). Regarding the influence of biometric parameters on PAHs bioaccumulation, it was found that $\Sigma \mathrm{PAHs}$ were negatively correlated with the mantle length of Octopus vulgaris caught in NEA, NWA, ECA, WCA and PO $(-0.018<\mathrm{r}<-0.695 ; p>0.05)$, as well as for Octopus maya $(\mathrm{r}=-0.053 ; p>0.05)$ and Eledone cirrhosa octopus 
( $\mathrm{r}=-0.515 ; p>0.05)$; only the samples of Octopus vulgaris from MS presented a weak but positive (and non-significant) correlation $(\mathrm{r}=0.300 ; p=0.624)$. Following the same tendency, the concentrations of individual compound presented a negative relation with the mantle length of Octopus vulgaris from NEA [Naph, Acen, Ace, Fln, Py, and $\mathrm{B}(\mathrm{k}) \mathrm{F}(-0.357<\mathrm{r}<-0.859 ; p \geq 0.006)$ ], NWA [ Flu, Ant, Fln, and B(a)A $(-0.133<\mathrm{r}<-0.552)$ ], ECA [Naph, Acen, Phe, and Py $(-0.198<\mathrm{r}<-0.364 ; p \geq 0.423)$ ], WCA [Ace, Phe, and Ant $(-0.108<\mathrm{r}<-0.245 ; p \geq 0.552)$ ], PO [Naph, Acen, Ace, Flu, Phe, Ant, Fln, and DB(a,h)A $(-0.255<\mathrm{r}<-0.534 ; p \geq 0.172)$ ], and MS [Fln ( $\mathrm{r}=-0.354 ; p=0.559)]$. Samples of Octopus maya also presented negative Spearman correlations between the mantle length and the levels of Naph, Py, and $\mathrm{B}(\mathrm{b}+\mathrm{j}) \mathrm{F}(-0.127<\mathrm{r}<-0.366 ; p \geq 0.163)$. Concentrations of Flu, Ant, Py, B(a)A, Chry, and B(g,h,i)P were also negatively associated with the mantle length of Eledone cirrhosa samples $(-0.415<\mathrm{r}<-0.768 ; p \geq 0.026)$. However, some positive and strong correlations were found between the mantle length and the concentrations of Fln $(\mathrm{r}=0.795 ; p=0.033)$, Flu $(\mathrm{r}=0.541$; $p=0.166), \mathrm{B}(\mathrm{a}) \mathrm{P}(\mathrm{r}=0.659 ; p=0.076)$, Рy $(\mathrm{r}=0.408 ; p=0.316)$, and Ace $(\mathrm{r}=0.707 ; p=0.182)$ in muscle tissues of Octopus vulgaris from ECA, WCA, NEA, PO, and MS, respectively. Samples of Eledone cirrhosa also presented positive and moderate to strong correlations between the mantle length and the concentrations of Naph, Ace, and B (a)P $(0.494<\mathrm{r}<0.639 ; \mathrm{p} \leq 0.213)$.

$\Sigma$ PAH levels were negatively correlated with the weight of Octopus vulgaris samples from ECA and NEA, Octopus maya, and Eledone cirrhosa, however significant correlations were only observed for Octopus vulgaris originated from NEA $(r=-0.714 ; p=0.05)$. A positive and moderate correlation coefficient was only found in Octopus vulgaris from MS $(r=0.616 ; p=0.269)$. The weight of octopus was negatively associated with the concentrations of Acen in Octopus vulgaris from ECA, WCA, and NEA $(-0.171<\mathrm{r}<-0.577 ; p \geq 0.134)$. Additionally, levels of Naph, Ace, Flu, Phe, Fln, Py, and B(k)F were also moderate to strongly correlated with the weight of Octopus vulgaris caught in NEA $(-0.265<\mathrm{r}<-0.732 ; p \geq 0.039)$. Samples of Eledone cirrhosa also presented negative correlations between the levels of Flu, Ant, Py, B (a)A, Chry, and B(a)P with the weight of octopus $(-0.464<\mathrm{r}<-0.655 ; p \geq 0.078)$. Previously Gomes et al. (2013) also reported negative correlations between total and some specific PAHs with the weight of squids.

Inconclusive results were obtained between total and individual PAH levels with fat content in octopus. A negative dependence was observed for $\mathrm{PPAHs}$ and fat in Octopus vulgaris from NEA, WCA, PO, and MS $\quad(-0.119<\mathrm{r}<-0.500 ; \quad p>0.05)$ and Octopus maya $(\mathrm{r}=-0.130 ; p>0.05)$ samples. However, Eledone cirrhosa and Octopus vulgaris from NWA and ECA presented positive but weak Spearman correlations ( $r \leq 0.500 ; p \geq 0.207$ ). Positive correlations were found between fat content with the levels of Naph, Acen, Ace, Flu, and Phe $(0.288<\mathrm{r}<0.778 ; p \geq 0.039)$, Ace, Phe, and Ant (0.214 $<\mathrm{r}<0.756 ; p \geq 0.027)$, and Flu, Phe, Py, B(b+j)F $(0.300<\mathrm{r}<0.707 ; p \geq 0.559)$ for Octopus vulgaris samples captured in ECA, WCA, and MS, respectively. Fat levels in Octopus maya samples presented positive relation with Naph, Flu, and Phe $(0.0 .307<\mathrm{r}<0.442 ; p \geq 0.086)$ but were negatively correlated with the levels of Acen ( $\mathrm{r}=-0.420 ; p=0.105)$, and Py $(\mathrm{r}=-0.364$; $p=0.165$ ). Samples of Eledone cirrhosa presented positive correlations between fat content and the levels of Flu, Phe, Ant, Py, B(a)A, Chry, and $\mathrm{B}(\mathrm{g}, \mathrm{h}, \mathrm{i}) \mathrm{P}(0.190<\mathrm{r}<0.571 ; p \geq 0.139)$ but a negative relation with Naph, Ace, and B(a)P $(-0.347<\mathrm{r}<-0.515 ; p \geq 0.192)$. However, more studies are needed to better clarify the dependency relation between the PAH levels and the biometric parameters of octopus.

\subsubsection{Geographical discrimination and source analysis}

The concentrations of individual and total PAHs in the edible tissues of octopus samples, organized by geographical origin (NEA, NWA, ECA, WCA, PO and MS), are presented in Table 6S. Overall, median $\Sigma$ PAHs varied between 8.60 (WCA) to 12.8 (NWA) $\mu \mathrm{g} / \mathrm{kg}$ w.w. in samples from Atlantic Ocean origin, being the concentrations found in NWA samples significantly higher than in NEA and WCA $(p \leq 0.050)$. In octopus from MS, $\Sigma$ PAHs ranged between 8.52 and $10.6 \mu \mathrm{g} / \mathrm{kg}$ w.w. (median $8.65 \mu \mathrm{g}$ / $\mathrm{kg} w \mathrm{w}$ ), while in species from PO waters levels varied from 8.10 to $37.0 \mu \mathrm{g} / \mathrm{kg}$ w.w. (median $8.59 \mu \mathrm{g} / \mathrm{kg}$ ww) (Table $6 \mathrm{~S}$ ). No significant differences $(p>0.05)$ were found between these two geographical origins. Thus, the series of $\Sigma$ PAHs among the three main different geographical origins were: Atlantic Ocean (NWA > ECA > NEA) > Atlantic Ocean $(\mathrm{WCA}) \approx \mathrm{MS} \approx \mathrm{PO}$ (Table $6 \mathrm{~S}$ ). PCA was explored to distinguish the geographical origin (regardless of Octopus species) based on the detected PAH concentrations. The best model was achieved with the concentrations of the most predominant PAHs (Naph, Acen, Ace, Flu, Phe, Ant, and Py) (Fig. 2S). A total of three significant factors (F1, F2, and F3) displayed eigenvalues $>1.07$ and expressed $81.83 \%$ of the total variability (Table 7S). F1 represented $40.25 \%$ of the data and the compounds Phe, Ant, Flu and Acen contributed the most (square cosines values from 0.579 to 0.751 ) for the discrimination of octopus caught in NWA from all the other geographical origins (with the exception of few samples from NEA), which is in agreement with the observed significant statistical differences ( $p \leq 0.05$; Table 6S). F2 characterized $26.26 \%$ of the original data variance and allowed differentiation between the samples of Octopus vulgaris caught in WCA from those from MS; limited separation was attained between the other origins (Fig. 2S a)). Acen and Py (square cosines $>0.530$ ) were the compounds that contributed more for that discrimination (Table 7S). A third function, F3, was moderately influenced by Naph (square cosines $=0.461$ ) which may help in the differentiation of samples caught in WCA waters (Fig. 2S b).

The major sources of PAHs into marine environments are the direct spillage or leakage of petroleum and/or its derivatives, atmospheric fallout (wet and dry deposition of particles and vapors), municipal and industrial effluents, and rivers run-off (Annamalai and Namasivayam, 2015; Gu et al., 2018a; Kannan and Perrotta, 2008; Wolska et al., 2012; Zhang et al., 2012). Once in the aquatic environments PAHs can be volatized, photolyzed, biodegraded, and absorbed/adsorbed to the water suspended particles and sediments (Yebra-Pimentel et al., 2015). Diagnostic concentration ratios, one of the most frequently used tools to identify the possible origin of PAHs, were calculated based on median values of PAH concentrations determined in octopuses (Table 3). Diagnostic ratios of total concentration of low (LMW) to high molecular weight (HMW) compounds were clearly higher than one (11.1 (WCA) to 17.2 (ECA)) suggesting that the detected PAHs originated from crude oil refining sources (Fig. 3S; Table 3) (Cheung et al., 2007; Ke et al., 2017). On the other hand, the other calculated ratios also pointed for the existence of combustion sources with the exception of Naph/Phe and Phe/Ant in NWA samples (Table 3). Several authors have shown that PAHs produced during combustions are deposited in marine sediments (Gu et al., 2018a; Tongo et al., 2017; Yunker et al., 2012; Wolska et al., 2012). Overall the results indicated that contribution of both pyrogenic and petrogenic sources existed and that predominance of one of this source cannot be established, which is in line with previous studies (Gomes et al., 2013; Ke et al., 2017). The low biodegradability and the hydrophobic nature of PAHs cause bioaccumulation in marine organisms principally in those with low metabolization rates, such as bivalve molluscs, crustaceans, mussels, and cephalopods to levels that can be higher than their concentrations in the surrounding environment (Almeida et al., 2012; Bandowe et al., 2014; Hwang et al., 2012). In that regard some authors have observed elevated bioavailabilities of PAHs in the vicinity of large harbours, urban areas, and localities strongly affected by petroleum pollution along European coastal waters (Olenycz et al., 2015; Robinson et al., 2017). The same authors (Olenycz et al., 2015) also found that PAHs were also bioavailable in some remote areas, revealing the impact of long-range atmospheric deposition. Thus, it is expected that the composition of complex $\mathrm{PAH}$ mixtures may change with the source and season, being strongly 
Table 3

PAHs diagnostic concentration ratios for the characterized octopus species.

\begin{tabular}{|c|c|c|c|c|c|c|c|c|c|c|}
\hline \multirow[t]{2}{*}{ Ratio } & \multicolumn{6}{|c|}{ Octopus vulgaris } & \multirow{2}{*}{$\begin{array}{l}\text { Octopus maya } \\
W C A\end{array}$} & \multirow{2}{*}{$\begin{array}{l}\begin{array}{l}\text { Eledone } \\
\text { cirrhosa }\end{array} \\
\text { NEA }\end{array}$} & \multirow[t]{2}{*}{ Source and Required range } & \multirow[t]{2}{*}{ Reference } \\
\hline & $N E A$ & NWA & $E C A$ & WCA & $P O$ & MS & & & & \\
\hline $\mathrm{Fln} /(\mathrm{Fln}+\mathrm{Py})$ & 0.5 & 0.5 & 0.5 & 0.5 & 0.5 & 0.5 & 0.5 & 0.5 & $\begin{array}{l}>0.5 \text { : Combustion of grasses, coal } \\
\text { and wood }\end{array}$ & De La Torre-Roche et al. (2009) \\
\hline Fln/Py & 1.1 & 1.1 & 13.1 & 1.1 & 1.1 & 1.1 & 1.1 & 1.1 & $>1$ : combustion & Budzinski et al. (1997) \\
\hline $\mathrm{B}(\mathrm{a}) \mathrm{A} /(\mathrm{B}(\mathrm{a}) \mathrm{A}+$ Chry $)$ & 0.6 & 0.6 & 0.6 & 0.6 & 0.6 & 0.6 & 0.6 & 0.6 & $\begin{array}{l}>0.2 \text { : Combustion; } \\
<0.2 \text { : Crude oil refining }\end{array}$ & Akyüz and Çabuk (2010) \\
\hline B(a)A/Chry & 1.2 & 1.2 & 1.2 & 1.2 & 1.2 & 1.2 & 1.2 & 1.2 & $\begin{array}{l}>1 \text { : Combustion; } \\
<1 \text { : Crude oil refining }\end{array}$ & King et al. (2004) \\
\hline Naph/Phe & 1.3 & 0.8 & 2.2 & 1.7 & 1.2 & 1.2 & 1.7 & 2.7 & $\begin{array}{l}>1 \text { : Combustion; } \\
<1 \text { : Crude oil refining }\end{array}$ & Ravindra et al. (2008) \\
\hline Phe/Ant & 6.5 & 10.7 & 6.8 & 4.8 & 8.3 & 7.0 & 5.0 & 7.7 & $<10$ : Combustion & Readman et al. (2002) \\
\hline Ant/(Ant + Phe $)$ & 0.1 & 0.1 & 0.1 & 0.2 & 0.1 & 0.1 & 0.2 & 0.2 & $\begin{array}{l}>0.1 \text { : Combustion; } \\
<0.1 \text { : Crude oil refining }\end{array}$ & Pies et al. (2008) \\
\hline$\Sigma \mathrm{LMW} / \Sigma \mathrm{HMW}^{\mathrm{a}}$ & 12.8 & 13.7 & 17.2 & 11.7 & 11.6 & 11.3 & 11.1 & 12.8 & $>1$ : Crude oil refining & Hornbuckle and Robertson (2010) \\
\hline
\end{tabular}

Naph - naphthalene, Phe - phenanthrene, Ant - anthracene, Fln - fluoranthene, Py - pyrene, $B(a) A$ - benz(a)anthracene, Chry - chrysene.

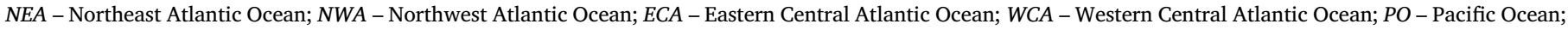
$M S$ - Mediterranean Sea.

${ }^{\text {a }} \Sigma$ LMW $/ \Sigma$ HMW $=$ (Naphthalene + Acenaphthylene + Acenaphthene + Fluorene + Phenanthrene + Anthracene + Fluoranthene + Pyrene + Benz(a)

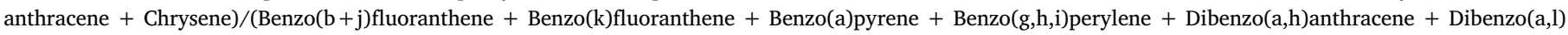
pyrene).

affected by the meteorological conditions of the environment (Rengarajan et al., 2015).

\subsection{Potential health risks for consumers}

Assessment of dietary intake of PAHs is important since some epidemiological studies demonstrated that dietary exposure to PAHs have been associated with breast, stomach, and gastrointestinal cancers (Abdel-Shafy and Mansour, 2016; Brody et al., 2007; Lee and Shim, 2007). The daily intake of $\Sigma$ PAHs based on world ( $0.51 \mathrm{~kg}$ per capita per year) and Portuguese (2.23 kg per capita per year) consumptions are presented in Table 4. Overall world per capita median ingestion of $\Sigma$ PAHs varied between $1.62-2.55 \times 10^{-4} \mu \mathrm{g} / \mathrm{kg}$ body weight per day; these results may be considered representative for French and Indonesian consumers ( $0.5 \mathrm{~kg}$ per capita per year) but also to the intake of Switzerland and Democratic People's Republic of Korean $(0.4 \mathrm{~kg}$ per capita per year) populations (FAO, 2018). Regarding Portuguese consumers, the contributions to the dietary exposure of $\Sigma$ PAHs were about 4 times higher, ranging from 7.09 to $11.2 \times 10^{-4} \mu \mathrm{g} / \mathrm{kg}$ body weight per day (Table 4). The assessed daily intake of $\Sigma \mathrm{PAHs}$ in Portugal can be considered indicative for other top consumers, namely Greek $(2.7 \mathrm{~kg}$ per capita per year), Italian (3.0 kg per capita per year), Spanish (3.2 kg per capita per year), and Asians from Macau and Hong-Kong (2.2-3.0 kg per capita per year), among others populations (FAO, 2018). The determined $\Sigma$ PAHs daily intake were higher than those reported by Domingo et al. (2007), Llobet et al. (2006), and Moon et al. (2010) for
Spanish and Korean consumers of cuttlefish (Sepia esculenta, Todarodes pacificus), squid (Loligo vulgaris), and octopus (Octopus minor) samples. Still, results from this study were in close range with the estimated PAHs daily intakes determined by Martí-Cid et al. $(2007,2008)$ for cuttlefish and squid samples acquired in Spain markets. Several factors influence the absorption rates of PAHs from the diet, namely the size of the molecule, their affinity to lipids, the presence of bile in the digestive tract, the dose ingested, and the lipid content of the diet (YebraPimentel et al., 2015).

$\mathrm{B}(\mathrm{a}) \mathrm{P}$, classified as carcinogenic to humans (IARC, 2010), was only detected in the edible tissues of Octopus vulgaris and Eledone cirrhosa octopus captured in NEA waters at levels $(0.06-0.13 \mu \mathrm{g} / \mathrm{kg}$ w.w; Table 2) in close range with those found in other cephalopod species (Fontcuberta et al., 2006; Gomes et al., 2013; Llobet et al., 2006; MartíCid et al., 2008; Martorell et al., 2010; Semedo et al., 2014). There are no specific maximum limits for the levels of $\mathrm{B}(\mathrm{a}) \mathrm{P}$ or other PAHs in the muscle tissues of cephalopods (European Commission, 2011). However, the concentrations of $\mathrm{B}(\mathrm{a}) \mathrm{P}$ in octopuses were well below the maximum limit of $5.0 \mu \mathrm{g} / \mathrm{kg}$ w.w. established by European Commission for bivalve molluscs (fresh, chilled or frozen) (European Commission, 2006). The European Food Safety Authority (EFSA) already stated that B(a)P, solely, is not a suitable marker for the occurrence of PAHs in food and proposed the sum of i) four specific compounds (B(a)P, B(a)A, B(b)F, and Chry; $\Sigma \mathrm{PAHs}_{4}$ ) and ii) eight PAHs (B(a)P, B(a)A, B(b)F, Chry, B(k)F, $\mathrm{B}(\mathrm{g}, \mathrm{h}, \mathrm{i}) \mathrm{P}, \mathrm{DB}(\mathrm{a}, \mathrm{h}) \mathrm{A}$, and Ind; $\left.\Sigma \mathrm{PAHs}_{8}\right)$ as the most appropriate indicators (European Commission, 2011; EFSA, 2008). With this system,

Table 4

Estimated daily intake of total PAHs (median and range; $\mu \mathrm{g} / \mathrm{kg}$ body weight per day) by the ingestion of the characterized octopus species .

\begin{tabular}{|c|c|c|c|c|c|c|c|c|c|c|}
\hline & \multirow{2}{*}{$\begin{array}{l}\text { Per capita } \\
\text { consumption }\end{array}$} & & \multicolumn{6}{|c|}{ Octopus vulgaris } & \multirow{2}{*}{$\begin{array}{l}\text { Octopus maya } \\
W C A\end{array}$} & \multirow{2}{*}{$\begin{array}{l}\begin{array}{l}\text { Eledone } \\
\text { cirrhosa }\end{array} \\
\text { NEA }\end{array}$} \\
\hline & & & $N E A$ & $N W A$ & $E C A$ & $W C A$ & $P O$ & MS & & \\
\hline \multirow[t]{2}{*}{ Intake $\left(\times 10^{-4}\right)$} & World & $\Sigma \mathrm{PAHs}$ & $\begin{array}{l}1.90 \\
(1.59-6.35)\end{array}$ & $\begin{array}{l}2.55 \\
(1.93-3.77)\end{array}$ & $\begin{array}{l}2.34 \\
(1.66-13.2)\end{array}$ & $\begin{array}{l}2.20 \\
(1.60-11.9)\end{array}$ & $\begin{array}{l}1.71 \\
(1.62-7.39)\end{array}$ & $\begin{array}{l}1.73 \\
(1.70-2.12)\end{array}$ & $\begin{array}{l}1.62 \\
(1.58-17.2)\end{array}$ & $\begin{array}{l}1.84 \\
(1.79-2.06)\end{array}$ \\
\hline & Portuguese & $\Sigma$ PAHs & $\begin{array}{l}8.47 \\
(6.96-27.8)\end{array}$ & $\begin{array}{l}11.2 \\
(8.46-16.5)\end{array}$ & $\begin{array}{l}10.2 \\
(7.26-58.8)\end{array}$ & $\begin{array}{l}9.60 \\
(7.01-51.9)\end{array}$ & $\begin{array}{l}7.50 \\
(7.07-32.3)\end{array}$ & $\begin{array}{l}7.55 \\
(7.44-9.25)\end{array}$ & $\begin{array}{l}7.09 \\
(6.91-75.3)\end{array}$ & $\begin{array}{l}8.06 \\
(7.85-8.99)\end{array}$ \\
\hline
\end{tabular}

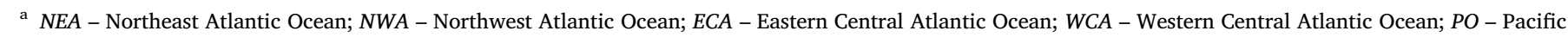
Ocean; $M S$ - Mediterranean Sea.

b Estimated daily intakes of total PAHs were determined based on the World and Portuguese per capita cephalopods consumption in 2013 according to FAO (2018). 


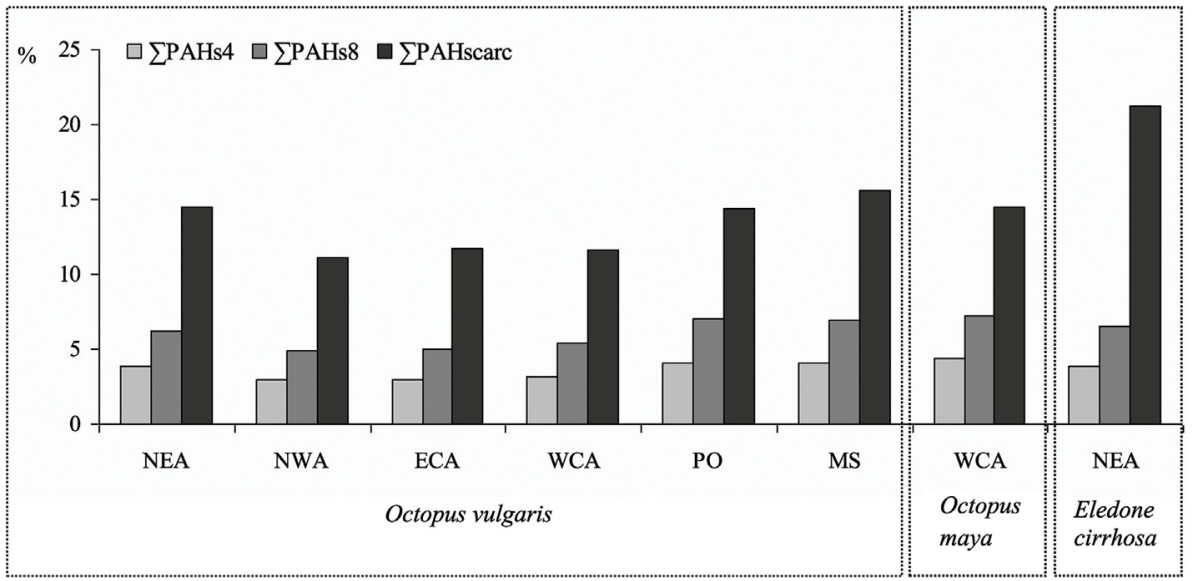

Fig. 3. Contribution (\%) of $\mathrm{\Sigma PAHs}_{4}$ [benzo(a) pyrene + benz(a)anthracene + benzo(b)fluoranthene + chrysene; European Commission, 2011], $\Sigma_{\text {PAHs }}\left[\mathrm{\Sigma PAHs}_{4}+\right.$ benzo(k)fluoranthene + benzo (g,h,i)perylene + dibenz(a,h)anthracene + indene (1,2,3-cd)pyrene; European Commission, 2011] and $\Sigma \mathrm{PAHs}_{\text {carc }}\left[\Sigma \mathrm{PAHs}_{8}+\right.$ naphthalene] to total PAHs ( $\mathrm{PAH}$ ) in the edible tissues of octopus samples available to Portuguese consumers. it is ensured that exposure to possible/probable carcinogenic PAH by food ingestion are kept at concentrations that do not cause health concern to populations even if B(a)P is not detected. Overall $\Sigma \mathrm{PAHs}_{4}$ and $\Sigma \mathrm{PAHs}_{8}$ concentrations ranged between 0.35 and $1.45 \mu \mathrm{g} / \mathrm{kg}$ w.w. and from 0.59 to $2.78 \mu \mathrm{g} / \mathrm{kg}$ w.w., representing $3.0-4.4 \%$ and $4.9-7.2 \%$ of $\Sigma$ PAHs, respectively (Fig. 3). The obtained concentrations of $\Sigma \mathrm{PAHs}_{4}$ were much lower than the limit of $30.0 \mu \mathrm{g} / \mathrm{kg}$ w.w. defined by the European Commission for bivalve molluscs (fresh, chilled or frozen; European Commission, 2011). Among the 18 selected PAHs, a total of eight probable/possible carcinogens in addition to $\mathrm{B}(\mathrm{a}) \mathrm{P}$ were considered (Naph, B(a)A, Chry, B(b)F, B(j)F, B(k)F, DB(a,h)A, and DB(a,l)P;

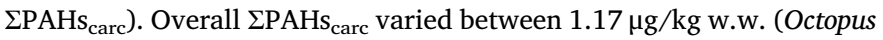
vulgaris from NEA and WCA; Octopus maya caught in WCA) to $1.94 \mu \mathrm{g} /$ $\mathrm{kg}$ w.w. (Eledone cirrhosa captured in NEA waters) and represented $11-21 \%$ of $\Sigma$ PAHs (Fig. 3). The compounds that contributed the most for $\Sigma$ PAHs carc $_{\text {cere Naph (43-69\% of } \Sigma \text { PAHs }}$ carc), followed by DB(a,h)A (4-29\%), B(b+j)F (11-17\%), and DB(a,1)P (8-12\%); the other compounds accounted with less than $10 \%$ of $\Sigma \mathrm{PAHs}_{\mathrm{carc}}$. According to EFSA
(2008) report, people exposure from the consumption of cephalopods including octopus ( $\Sigma \mathrm{PAHs}_{8}: 0.01-0.77 \mu \mathrm{g} / \mathrm{kg}$ ) is much lower than the exposure associated with the ingestion of other food items namely dried tea products $(61.02-61.14 \mu \mathrm{g} / \mathrm{kg})$, food supplements (30.03-30.31 $\mu \mathrm{g} /$ $\mathrm{kg})$, food with spices $(28.19-28.40 \mu \mathrm{g} / \mathrm{kg})$, pomace oil $(27.74-27.90 \mu \mathrm{g} / \mathrm{kg})$, preserved and processed fish $(23.17-23.92 \mu \mathrm{g} /$ $\mathrm{kg}$ ), cocoa butter (18.36-18.65 $\mu \mathrm{g} / \mathrm{kg}$ ), coffee powder (16.95-17.94 $\mu \mathrm{g}$ / $\mathrm{kg}$ ), all bivalve molluscs $(15.42-15.58 \mu \mathrm{g} / \mathrm{kg})$, and barbequed and grilled meats $(3.29-7.96 \mu \mathrm{g} / \mathrm{kg})$.

$\mathrm{TEQ}_{\mathrm{B}(\mathrm{a}) \mathrm{P}}$ concentrations, i.e., the sum of TEF-adjusted concentrations for each $\mathrm{PAH}$ are presented in Fig. 4a. In general, $\mathrm{TEQ}_{\mathrm{B}(\mathrm{a}) \mathrm{P}}$ median values were in the range of $16.6-18.6 \mu \mathrm{g} / \mathrm{kg}$ w.w. with samples of $O c$ topus vulgaris from NWA and PO reaching a maximum level of 27.8 and $29.0 \mu \mathrm{g} / \mathrm{kg}$ w.w., respectively. The concentrations range of $\mathrm{DB}(\mathrm{a}, \mathrm{l}) \mathrm{P}$ $(0.16-0.27 \mu \mathrm{g} / \mathrm{kg}$ w.w.) and $\mathrm{DB}(\mathrm{a}, \mathrm{h}) \mathrm{A}(0.12-2.58 \mu \mathrm{g} / \mathrm{kg}$ w.w.) in the muscle tissues of the selected species (Table 2) were low, however due to the high TEF values of these compounds, these were the PAHs that contributed the most for $\mathrm{TEQ}_{\mathrm{B}(\mathrm{a}) \mathrm{P}}(86.7-96.2 \%$ and $3.21-12.7 \%$ of
A

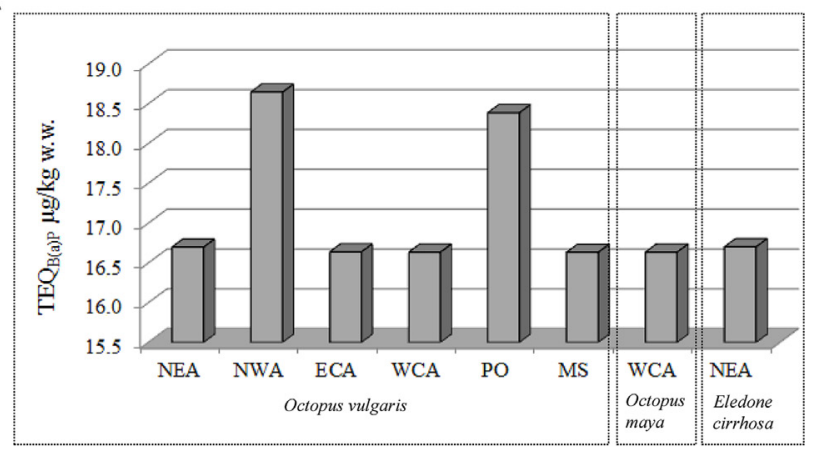

B

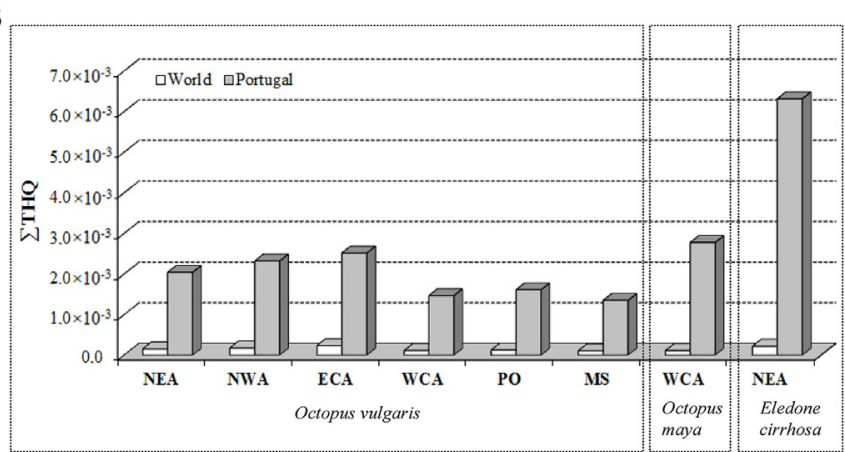

C

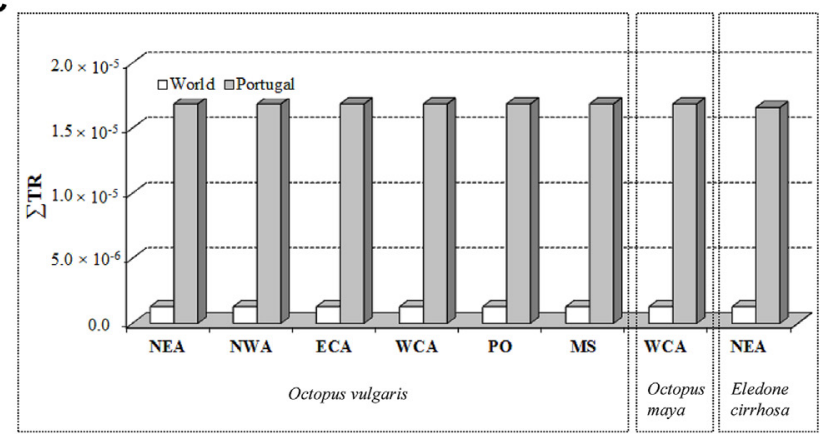

Fig. 4. Estimation of potential health risks for consumers due to the intake of PAHs in the characterized octopus species: a) total toxic benzo(a)pyrene equivalent $\left(\mathrm{TEQ}_{\mathrm{B}(\mathrm{a}) \mathrm{P}}\right)$; b) total non-carcinogenic (THQ) median risks; and c) total carcinogenic (TR) median risks. 
$\mathrm{TEQ}_{\mathrm{B}(\mathrm{a}) \mathrm{P}}$, respectively. These findings emphasize the importance in the analysis of these two potent carcinogenic compounds in the estimation of potential health risks associated with food consumption, even when low detection rates are observed.

THQ and TR risks were determined according to USEPA methodology (USEPA, 2017) for both World and Portuguese consumers (Fig. 4b-c). THQ represent the level of exposure below which, it is improbable that even the most sensitive populations, will experience potential health effects (USEPA, 1989). $\Sigma$ THQ median values for World and Portuguese consumers of octopus ranged from 1.07-2.35 $\times 10^{-4}$ (median $1.41 \times 10^{-4}$ ) and from 1.35-6.32 $\times 10^{-3}$ (median $2.18 \times 10^{-3}$ ), respectively, being the Octopus vulgaris caught in ECA, Octopus maya from WCA, and Eledone cirrhosa octopus captured in NEA the samples that exhibited the highest median values (Fig. 4b). Naph and Ace were the PAHs that contributed the most for $\Sigma$ THQ, accounting with $40-80 \%$ and $8-43 \%$, respectively (Fig. 4S). Still, $\Sigma$ THQ values were always well below the unitary limit defined by USEPA (2017) indicating that there may be no concern for potential non-carcinogenic effects. Regarding carcinogenic risks, $\Sigma T R$ levels varied from $1.22 \times 10^{-6}$ to $1.66 \times 10^{-5}$ (median $1.29 \times 10^{-6}$ ) for World and between $1.60 \times 10^{-5}$ to $2.18 \times 10^{-4}$ (median $1.69 \times 10^{-5}$ ) for Portuguese consumers (about 13 times higher) (Fig. 4c). Altogether, the PAHs DB(a,h)A and B(a)P contributed to $29-58 \%$ of $\Sigma T R$, being these results in line with the findings of Martí-Cid et al. (2008). Acceptable carcinogenic risks range between $10^{-4}$ to $10^{-6}$, i.e., a risk of an individual to develop cancer, over a lifetime, is respectively 1 in 10000 and 1 in 1000000 as a consequence of exposure to the potential carcinogen (USEPA, 1989). $\Sigma$ TR median values were all lower than the USEPA recommended safety limits, thus revealing that the exposure levels were low and, consequently, ingestion of the selected octopus species do not pose carcinogenic risks for low or high consumers. These data are in agreement with Martí-Cid et al. (2008), Moon et al. (2010), and Rodríguez-Hernández et al. (2016) that estimated cancer risks from total seafood consumption (fish, bivalve, crustacean, and cephalopod among other marine species) for the general Spanish and Korean population, which slightly exceeded the guideline value of $10^{-6}$. However, it is important to mention that, in this study, the potential health risks were based on raw and unprocessed food, and it is known that PAHs may also be formed during cooking, particularly during grilling, roasting, and frying foods (Abdel-Shafy and Mansour, 2016; Lee et al., 2016; Rose et al., 2015; Singh et al., 2016; Yebra-Pimentel et al., 2015; dos Santos Fogaça et al., 2018). The presence of other carcinogenic group of compounds in foodstuffs together with certain life styles of the populations may conduct to some risks, especially if synergistic effects occur (Gu et al., 2017, 2018b; Semedo et al., 2012; Vieira et al., 2011). Furthermore, the bioaccessibility of each hazardous compound may have a huge reduction impact on the real amount absorbed by the gastrointestinal tract and therefore on dietary exposure (dos Santos Fogaça et al., 2018; Gu et al., 2018b). 


\section{Conclusions}

This study fills a gap concerning the levels of 18 PAHs in the raw tissues of Octpus vulgaris, Octopus maya and Eledone cirrhosa captured in six different geographical origins. Overall, Octopus vulgaris presented the highest levels of $\Sigma$ PAHs, being followed by Eledone cirrhosa and Octopus maya. Discriminant analysis allowed the differentiation among the three species of octopus. This work also provided information on the daily intake of $\Sigma \mathrm{PAHs}$ for low and high consumers of cephalopods $\left(1.62-2.55 \times 10^{-4} \mu \mathrm{g} / \mathrm{kg}\right.$ body weight per day versus 7.09 to $11.2 \times 10^{-4} \mu \mathrm{g} / \mathrm{kg}$ body weight per day). B(a)P was only detected at low levels in the edible tissues of some specimens of Octopus vulgaris and Eledone cirrhosa. Health risk assessment revealed that non-carcinogenic effects and carcinogenic risks due to the consumption of raw octopus for low and high consumers are negligible. However, several studies have demonstrated that some culinary treatments and cooking practices (frying, grilling, barbecuing, toasting, and roasting) may increase the levels of PAHs in foodstuffs. Therefore, further studies regarding the impact of cooking activities on seafood are needed to better estimate the dietary intake of PAHs and the consequent potential health risks for consumers. Additionally, studies reporting PAHs bioaccessibility data are urgently needed in order to perform a more comprehensive characterization.

\section{Acknowledgements}

This work was supported by European Union (FEDER funds through COMPETE) and National Funds (Fundação para a Ciência e Tecnologia) through projects UID/QUI/50006/2013 and POCI-01-0145-FEDER007265, by the FCT/MEC with national funds and co-funded by FEDER in the scope of the P2020 Partnership Agreement. Additional financial support was provided by Fundação para a Ciência e a Tecnologia through fellowships SFRH/BD/52502/2014 (Filipa Gomes) and PD/ BD/109660/2015 (Álvaro Torrinha).

\section{References}

Abdel-Shafy, H.I., Mansour, M.S.M., 2016. A review on polycyclic aromatic hydrocarbons: source, environmental impact, effect on human health and remediation. Egyptian J. Petrol. 25, 107-123.

Akyüz, M., Çabuk, H., 2010. Gas and particle partitioning and seasonal variation of polycyclic aromatic hydrocarbons in the atmosphere of Zonguldak. Turkey. Sci. Total Environ. 408, 5550-5558.

Almeida, J.R., Gravato, C., Guilhermino, L., 2012. Challenges in assessing the toxic effects of polycyclic aromatic hydrocarbons to marine organisms: a case study on the acute toxicity of pyrene to the European seabass (Dicentrarchus labrax L.). Chemosphere 86, 926-937.

Annamalai, J., Namasivayam, V., 2015. Endocrine disrupting chemicals in the atmosphere: their effects on human and wildlife. Environ. Int. 76, 78-97.

AOAC, 2007. Official Methods of Analysis of AOAC International, eighteenth ed. AOAC International, Arlington

Bandowe, B.A.M., Bigalke, M., Boamah, L., Nyarko, E., Saalia, F.K., Wilcke, W., 2014. Polycyclic aromatic compounds (PAHs and oxygenated PAHs) and trace metals in fish species from Ghana (West Africa): bioaccumulation and health risk assessment. Environ. Int. 65, 135-146.

Bansal, V., Kim, K.-H., 2015. Review of PAH contamination in food products and their health hazards. Environ. Int. 84, 26-38.

Bordajandi, L.R., Gomez, G., Abad, E., Rivera, J., Fernandez-Baston, M.D.M., Blasco, J., Gonzalez, M.J., 2004. Survey of persistent organochlorine contaminants (PCBs, $\mathrm{PCDD} / \mathrm{Fs}$, and PAHs), heavy metals ( $\mathrm{Cu}, \mathrm{Cd}, \mathrm{Zn}, \mathrm{Pb}$, and $\mathrm{Hg}$ ), and arsenic in food samples from Huelva (Spain): levels and health implications. J. Agric. Food Chem. 52, 992-1001

Boström, C.E., Gerde, P., Hanberg, A., Jernstrom, B., Johansson, C., Kyrklund, T., Rannug, A., Tornqvist, M., Victorin, K., Westerholm, R., 2002. Cancer risk assessments, indicators, and guidelines for polycyclic aromatic hydrocarbons in the ambient air. Environ. Health Perspect. 10, 451-488.

Brody, J.G., Moysich, K.B., Humblet, O., Attfield, K.R., Beehler, G.P., Rudel, R.A., 2007. Environmental pollutants and breast cancer: epidemiologic studies. Cancer 109 (12), 2667-2711.

Budzinski, H., Jones, I., Bellocq, J., Pierard, C., Garrigues, P., 1997. Evaluation of sediment contamination by polycyclic aromatic hydrocarbons in the Gironde estuary. Mar. Chem. 58, 85-97.

Cheung, K.C., Leung, H.M., Kong, K.Y., Wong, M.H., 2007. Residual levels of DDTs and PAHs in freshwater and marine fish from Hong Kong markets and their health risk assessment. Chemosphere 66, 460-468.

De La Torre-Roche, R.J., Lee, W.-Y., Campos-Díaz, S.I., 2009. Soil-borne polycyclic aromatic hydrocarbons in El Paso, Texas: analysis of a potential problem in the United 
States/Mexico border region. J. Hazard Mater. 163, 946-958.

Domingo, J.L., Nadal, M., 2015. Human dietary exposure to polycyclic aromatic hydrocarbons: a review of the scientific literature. Food Chem. Toxicol. 86, 144-153.

Domingo, J.L., Bocio, A., Falcó, G., Llobet, J.M., 2007. Benefits and risks of fish consumption Part I. A quantitative analysis of the intake of omega-3 fatty acids and chemical contaminants. Toxicology 230, 219-226.

dos Santos Fogaça, F., Soares, C., Oliveira, M., Alves, R.N., Maulvault, A.L., Barbosa, V.L., Anacleto, P., Magalhães, J.A., Bandarra, N.M., Ramalhosa, M.J., Morais, S., Marques, A., 2018. Polycyclic aromatic hydrocarbons bioaccessibility in seafood: culinary practices effects on dietary exposure. Environ. Res. 164, 165-172.

EFSA, 2008. Adopted 9 June 2008. The EFSA Journal, 2008. Scientific opinion of the panel on contaminants in the food chain on a Request from the European Commission on polycyclic aromatic hydrocarbons in food 724. pp. 1-114. 3. http://www.efsa. europa.eu/sites/default/files/scientific_output/files/main_documents/724.pdf, Accessed date: 14 February 2017.

European Commission, 2006. Regulation (EC) No. 1881/2006 of 19 December 2006 Setting maximum levels for certain contaminants in foodstuffs. Off. J. Eur. Union L364, 5-24.

European Commission, 2011. Regulation (EC) No. 835/2011 of 19 August 2011 amending Regulation (EC) $\mathrm{N}^{\circ} 1881 / 2006$ as regards maximum levels for polycyclic aromatic hydrocarbons in foodstuffs. Off. J. Eur. Union L215, 4-8.

FAO, 2007. Future Prospects for Fish and Fishery Products, 4. Fish Consumption in the European Union in 2015 and 2030, Part 1. European Overview. Food and Agriculture Organization of the United Nations, Rome FAO Fisheries Circular No. 972/4

FAO, 2018. Fishery Statistical Collections, Consumption of Fish and Fishery Products FAOSTAT Consumption. Fishery and Aquaculture Department. Food and Agriculture Organization of the United Nations Available at: http://www.fao.org/fishery/ statistics/global-consumption/en, Accessed date: 12 July 2018.

Fontcuberta, M., Arqués, J.F., Martínez, M., Suárez, A., Villalbí, J.R., Centrich, F., Serrahima, E., Duran, J., Casas, C., 2006. Polycyclic aromatic hydrocarbons in food samples collected in Barcelona, Spain. J. Food Protect. 69, 2024-2028.

Gomes, F., Oliveira, M., Ramalhosa, M.J., Delerue-Matos, C., Morais, S., 2013. Polycyclic aromatic hydrocarbons in commercial squids from different geographical origins: levels and risks for human consumption. Food Chem. Toxicol. 59, 46-54.

Gu, Y.G., Lin, Q., Huang, H.H., Wang, L.G., Ning, J.J., Du, F.Y., 2017. Heavy metals in fish tissues/stomach contents in four marine wild commercially valuable fish species from the western continental shelf of south China Sea. Mar. Pollut. Bull. 114 (2), $1125-1129$.

Gu, Y.G., Ke, C.L., Liu, Q., 2018a. Characterization, sources, and ecological hazards of polycyclic aromatic hydrocarbons in the intertidal sediments of Zhelin Bay, the biggest mariculture area of the eastern Guangdong coast of China. Mar. Pollut. Bull. 130, 192-197.

Gu, Y.G., Ning, J.J., Ke, C.L., Huang, H.H., 2018b. Bioaccessibility and human health implications of heavy metals in different trophic level marine organisms: a case study of the South China Sea. Ecotoxicol. Environ. Saf. 163, 551-557.

Hornbuckle, K., Robertson, L., 2010. Polychlorinated biphenyls (PCBs): sources, exposures, toxicities. Environ. Sci. Technol. 44, 2749-2751.

Hornung, R.W., Reed, L.D., 1990. Estimation of average concentration in the presence of nondetectable values. Appl. Occup. Environ. Hyg 5, 46-51.

Hwang, K., Woo, S., Choi, J., Kim, M., 2012. Survey of polycyclic aromatic hydrocarbons in marine products in Korea using G.C./M.S. Food Addit. Contam. B 1-7.

IARC, 2002. Some traditional herbal medicines, some mycotoxins, naphthalene and styrene. Working Group on the Evaluation of Carcinogenic Risks to Humans, IARC Monographs on the Evaluation of Carcinogenic Risks to Humans, vol. 82. International Agency for Research on Cancer, pp. 1-556.

IARC, 2010. Some non-heterocyclic polycyclic aromatic hydrocarbons and some related exposures. Working Group on the Evaluation of Carcinogenic Risks to Humans, IARC Monographs on the Evaluation of Carcinogenic Risks to Humans, vol. 92. International Agency for Research on Cancer, pp. 1-853.

INE, 2018. Estatística de pesca 2017. Instituto Nacional de Estatística. IP. Lisbon.

Kalogeropoulos, N., Karavoltsos, S., Sakellari, A., Avramidou, S., Dassenakis, M., Scoullos, M., 2012. Heavy metals in raw, fried and grilled Mediterranean finfish and shellfish. Food Chem. Toxicol. 50, 3702-3708.

Kannan, K., Perrotta, E., 2008. Polycyclic aromatic hydrocarbons (PAHs) in livers of California sea otters. Chemosphere 71, 649-655.

Ke, C.-L., Gu, Y.-G., Liu, Q., Li, L.-D., Huang, H.-H., Cai, N., Sun, Z.-W., 2017. Polycyclic aromatic hydrocarbons (PAHs) in wild marine organisms from South China Sea: occurrence, sources, and human health implications. Mar. Pollut. Bull. 117, 507-511.

King, A., Readman, J., Zhou, J., 2004. Dynamic behaviour of polycyclic aromatic hydrocarbons in Brighton marina, UK. Mar. Pollut. Bull. 48, 229-239.

Lee, B.M., Shim, G.A., 2007. Dietary exposure estimation of benzo[a]pyrene and cancer risk assessment. J. Toxicol. Environ. Health 70 (15-16), 1391-1394.

Lee, J.-G., Kim, S.-Y., Moon, J.-S., Kim, S.-H., Kang, D.-H., Yoon, H.-J., 2016. Effects of grilling procedures on levels of polycyclic aromatic hydrocarbons in grilled meats. Food Chem. 199, 632-638.

Llobet, J.M., Falcó, G., Bocio, A., Domingo, J.L., 2006. Exposure to polycyclic aromatic hydrocarbons through consumption of edible marine species in Catalonia, Spain. J. Food Protect. 69, 2493-2499.

Martí-Cid, R., Bocio, A., Llobet, J.M., Domingo, J.L., 2007. Intake of chemical contaminants through fish and seafood consumption by children of Catalonia, Spain: health risks. Food Chem. Toxicol. 45, 1968-1974.

Martí-Cid, R., Llobet, J.M., Castell, V., Domingo, J.L., 2008. Evolution of the dietary exposure to polycyclic aromatic hydrocarbons in Catalonia, Spain. Food Chem. Toxicol. 46, 3163-3171.

Martorell, I., Perelló, G., Martí-Cid, R., Castell, V., Llobet, J.M., Domingo, J.L., 2010. Polycyclic aromatic hydrocarbons (P.A.H.) in foods and estimated P.A.H. intake by the population of Catalonia, Spain: temporal trend. Environ. Int. 36, 424-432.

Moon, H.-B., Kim, H.-S., Choi, M., Choi, H.-G., 2010. Intake and potential health risk of polycyclic aromatic hydrocarbons associated with seafood consumption in Korea from 2005 to 2007. Arch. Environ. Contam. Toxicol. 58, 214-221.

Muller, P., Leece, B., Raha, D., 1997. Scientific Criteria Document for Multimedia Standards Development: Polycyclic Aromatic Hydrocarbons (PAHs). Part 1: Hazard Identification and Dose-response Assessment. Ministry of Environment and Energy, Ontario.

Nisbet, I.C.T., LaGoy, P.K., 1992. Toxic equivalency factors (TEFs) for polycyclic aromatic hydrocarbons (PAHs). Regul. Toxicol. Pharmacol. 16, 290-300.

Okona-Mensah, K.B., Battershill, J., Boobis, A., Fielder, R., 2005. An approach to in vestigating the importance of high potency polycyclic aromatic hydrocarbons (PAHs) in the induction of lung cancer by air pollution. Food Chem. Toxicol. 43, 1103-1116.

Olenycz, M., Sokołowski, A., Niewińska, A., Wołowicz, M., Namieśnik, J., Hummel, H., Jansen, J., 2015. Comparison of PCBs and PAHs levels in European coastal waters using mussels from the Mytilus edulis complex as biomonitors. Oceanology 57, $196-211$.

Ozogul, Y., Duysak, O., Ozogul, F., Özkütük, A., Türeli, C., 2008. Seasonal effects in the nutritional quality of the body structural tissue of cephalopods. Food Chem. 108, 847-852.

Perugini, M., Visciano, P., Giammarino, A., Manera, M., Di Nardo, W., Amorena, M., 2007a. Polycyclic aromatic hydrocarbons in marine organisms from the Adriatic Sea Italy. Chemosphere 66, 1904-1910.

Perugini, M., Visciano, P., Manera, M., Turno, G., Lucisano, A., Amorena, M., 2007b. Polycyclic aromatic hydrocarbons in marine organisms from the Gulf of Naples, Tyrrhenian Sea. J. Agric. Food Chem. 55, 2049-2054.

Pies, C., Hoffmann, B., Petrowsky, J., Yang, Y., Ternes, T.A., Hofmann, T., 2008. Characterization and source identification of polycyclic aromatic hydrocarbons (PAHs) in river bank soils. Chemosphere 72, 1594-1601.

Ramalhosa, M.J., Paíga, P., Morais, S., Delerue-Matos, C., Oliveira, M.B.P.P., 2009. Analysis of polycyclic aromatic hydrocarbons in fish: evaluation of a quick, easy, cheap, effective, rugged, and safe extraction method. J. Separ. Sci. 32, 3529-3538.

Ramalhosa, M.J., Paíga, P., Morais, S., Ramos, S., Delerue-Matos, C., Oliveira, M.B.P.P., 2012a. Polycyclic aromatic hydrocarbon levels in three pelagic fish species from Atlantic Ocean: inter-specific and inter-season comparisons and assessment of potential public health risks. Food Chem. Toxicol. 50, 162-167.

Ramalhosa, M.J., Paíga, P., Sousa, A.M.M., Gonçalves, M.P., Morais, S., Delerue-Matos, C., Oliveira, M.B.P.P., 2012b. Analysis of polycyclic aromatic hydrocarbons in fish: optimization and validation of microwave-assisted extraction. Food Chem. 135, 234-242.

Ravindra, K., Sokhi, R., Van Grieken, R., 2008. Atmospheric polycyclic aromatic hydrocarbons: source attribution, emission factors and regulation. Atmos. Environ. 42, 2895-2921.

Readman, J.W., Filmann, G., Tolosa, I., Bartocci, J., Villeneuve, J.-P., Catinni, C., Mee, L.D., 2002. Petroleum and PAH contamination of the black sea. Mar. Pollut. Bull. 44, 48-62.

Rengarajan, T., Rajendran, P., Nandakumar, N., Lokeshkumar, B., Rajendran, P., Nishigaki, I., 2015. Exposure to polycyclic aromatic hydrocarbons with special focus on cancer. Asian Pac. J. Trop. Biomed. 5 (3), 182-189.

Robinson, C.D., Webster, L., Martínez-Gómez, C., Burgeot, T., Gubbins, M.J., Thain, J.E., Dick Vethaak, A., McIntosh, A.D., 2017. Assessment of contaminant concentrations in sediments, fish and mussels samples from the North Atlantic and European regional seas within the ICON project. Mar. Environ. Res. 124, 21-31.

Rodríguez-Hernández, Á., Camacho, M., Henríquez-Hernández, L.A., Boada, L.D., RuizSuárez, N., Valerón, P.F., González, M.A., Zaccaroni, A., Zumbado, M., Luzardo, O.P., 2016. Assessment of human health hazards associated with the dietary exposure to organic and inorganic contaminants through the consumption of fishery products in Spain. Sci. Total Environ. 557-558, 808-818.

Rose, M., Holland, J., Dowding, A., Petch, E.R.C., White, S., Fernandes, A., Mortimer, D., 2015. Investigation into the formation of PAHs in foods prepared in the home to determine the effects of frying, grilling, barbecuing, toasting and roasting. Food Chem. Toxicol. 78, 1-9.

Semedo, M., Reis-Henriques, M.A., Rey-Salgueiro, L., Oliveira, M., Delerue-Matos, C., Morais, S., Ferreira, M., 2012. Metal accumulation and oxidative stress biomarkers in octopus (Octopus vulgaris) from Northwest Atlantic. Sci. Total Environ. 433, 230-237.

Semedo, M., Oliveira, M., Gomes, F., Reis-Henriques, M.A., Delerue-Matos, C., Morais, S., Ferreira, M., 2014. Seasonal patterns of polycyclic aromatic hydrocarbons in digestive gland and arm of octopus (Octopus vulgaris) from the Northwest Atlantic. Sci. Total Environ. 481, 488-497.

Singh, L., Varshney, J.G., Agarwal, T., 2016. Polycyclic aromatic hydrocarbons' formation and occurrence in processed food. Food Chem. 199, 768-781.

Storelli, M.M., 2008. Potential human health risks from metals ( $\mathrm{Hg}, \mathrm{Cd}$, and $\mathrm{Pb}$ ) and polychlorinated biphenyls (PCBs) via seafood consumption: estimation of target hazard quotients (THQs) and toxic equivalents (TEQs). Food Chem. Toxicol. 46, 2782-2788.

Tongo, I., Ezemonye, L., Akpeh, K., 2017. Levels, distribution and characterization of polycyclic aromatic hydrocarbons (PAHs) in Ovia river, Southern Nigeria. J. Environ. Chem. Eng. 5, 504-512.

Torrinha, Á., Cruz, R., Gomes, F., Mendes, E., Casal, S., Morais, S., 2014. Octopus lipid and Vitamin E composition: interspecies, interorigin, and nutritional variability. J. Agric. Food Chem. 62, 8508-8517.

UNECE, 1998. Protocol on Persistent Organic Pollutants under the 1979 Convention on Long Range Transport Air Pollution, ECE/EB.Air/60. United Nations Economic Commission for Europe, Geneva, Switzerland.

Unger, M.A., Harvey, E., Vadas, G.G., Vecchione, M., 2008. Persistent pollutants in nine 
speciesofdeep-seacephalopods.Mar.Pollut.Bull.56,1486-1512.

USEPA,1989.Riskassessmentguidanceforsuperfund.HumanHealthEvaluation

Manual,vol.IOfficeofEmergencyandRemedialResponse,Washington,DCEPA/

540/1-89/002.

USEPA,2005.GuidelinesforCarcinogenRiskAssessmentEPA/630/P-03/001F.US

EnvironmentalProtectionAgency,Washington,D.C.,UnitedStatesofAmerica

Availableat:https://www.epa.gov/sites/production/files/2013-09/documents/

cancerguidelinesfinal_3-25-05.pdf,Accesseddate:14April2017.

USEPA,2011.ExposureFactorsHandbook2011Edition(Final).UnitedStates

EnvironmentalProtectionAgency,Washington,DC

USEPA,2017.RiskBasedConcentrationTable.Availableat:https://www.epa.gov/ sites/production/files/2016-06/documents/master_sl_table_run_may2016.pdf,

Accesseddate:14June2018.

Vecchione,M.,2017.Cephalopods.NationalMarineFisheriesService,NationalMuseum

ofNaturalHistory,Washington,D.C.,USA,pp.150-166.Availableat:ftp://

ftp.fao.org/docrep/fao/009/y4160e/y4160e10.pdf,Accesseddate:2February 2017.

Vieira, C., Morais, S., Ramos, S., Delerue-Matos, C., Oliveira, M.B.P.P., 2011. Mercury, cadmium, lead and arsenic levels in three pelagic fish species from the Atlantic Ocean: intra- and inter-specific variability and human health risks for consumption. Food Chem. Toxicol. 49, 923-932.

WHO, 2013. State of the Science of Endocrine Disrupting Chemicals 2012. United Nations Environment Programme and the World Health Organization, Geneva.

Wolska, L., Nska, A.M., Rogowska, J., Namiesnik, J., 2012. Sources and fate of PAHs and PCBs in the marine environment. Crit. Rev. Environ. Sci. Technol. 42, 1172-1189.

Yebra-Pimentel, I., Fernández-González, R., Martínez-Carballo, E., Simal-Gándara, J. 2015. A critical review about the health risk assessment of PAHs and their metabolites in foods. Crit. Rev. Food Sci. 55, 1383-1405.

Yunker, M.B., Perreault, A., Lowe, C.J., 2012. Source apportionment of elevated PAH concentrations in sediments near deep marine outfalls in Esquimalt and Victoria, B.C., Canada: is coal from an 1891 shipwreck the source? Org. Geochem. 46, 12-37.

Zhang, K., Liang, B., Wang, J.-Z., Guan, Y.-F., Zeng, E.Y., 2012. Polycyclic aromatic hydrocarbons in upstream riverine runoff of the Pearl River Delta, China: an assessment of regional input sources. Environ. Pollut. 167, 78-84. 